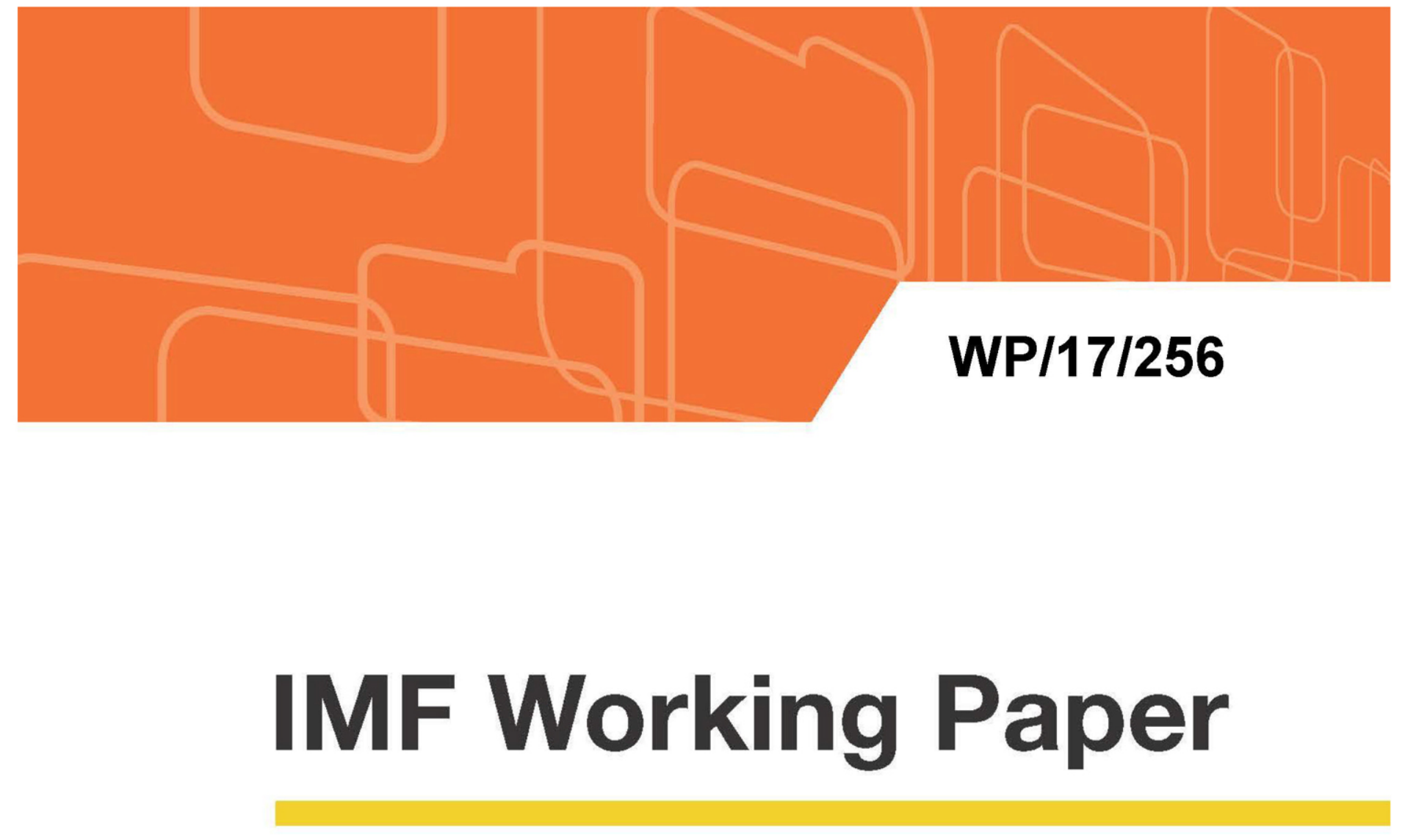

\title{
Credit Growth and Economic Recovery in Europe After the Global Financial Crisis
}

by Sergei Antoshin, Marco Arena, Nikolay Gueorguiev,

Tonny Lybek, John Ralyea and Etienne B. Yehoue

IMF Working Papers describe research in progress by the author(s) and are published to elicit comments and to encourage debate. The views expressed in IMF Working Papers are those of the author(s) and do not necessarily represent the views of the IMF, its Executive Board, or IMF management.

$$
\text { I N T E R N A T I O N A L M O N E T A R Y F U N D }
$$




\section{WP/17/256}

\section{IMF Working Paper}

\section{Credit Growth and Economic Recovery in Europe After the Global Financial Crisis}

by Sergei Antoshin, Marco Arena, Nikolay Gueorguiev,

Tonny Lybek, John Ralyea and Etienne B. Yehoue

IMF Working Papers describe research in progress by the author(s) and are published to elicit comments and to encourage debate. The views expressed in IMF Working Papers are those of the author(s) and do not necessarily represent the views of the IMF, its Executive Board, or IMF management.

$$
\text { I N T E R N A T I O N A L M O N E T A R Y F U N D }
$$




\title{
IMF Working Paper
}

European Department

\author{
Credit Growth and Economic Recovery in Europe After the Global Financial Crisis \\ Prepared by Sergei Antoshin, Marco Arena, Nikolay Gueorguiev, Tonny Lybek, John \\ Ralyea and Etienne Yehoue ${ }^{1}$
}

Authorized for distribution by Nikolay Gueorguiev

November 2017

\begin{abstract}
IMF Working Papers describe research in progress by the author(s) and are published to elicit comments and to encourage debate. The views expressed in IMF Working Papers are those of the author(s) and do not necessarily represent the views of the IMF, its Executive Board, or IMF management.
\end{abstract}

\begin{abstract}
This paper reviews the empirical relationships between credit growth, economic recovery, and bank profitability in Europe after the global financial crisis (GFC). We find that the postGFC recoveries in Europe have been weaker than previous recoveries, with the "double-dip" recessions in 2011-12 in many countries and the worldwide reach of the GFC explaining the underperformance. Bank lending has been subdued as well, but this appears to have only held back the recovery relatively moderately. A 10 percent increase in bank credit to the private sector is associated with a rise of $0.6-1$ percent in real GDP and 2-2 $\frac{1}{2}$ percent in real private investment. These relationships have not changed significantly during and after the GFC. Loan quality, customer deposits, bank equity price index, and bank capital appear to be closely linked to bank lending. As expected, bank profitability is positively and significantly influenced by credit growth, but this relationship has weakened after the GFC.
\end{abstract}

JEL Classification Numbers: C23, C26, E51, G01, G21, O47, O52;

Keywords: credit growth, economic recovery, creditless recoveries, bank profitability, global financial crisis, Europe

Authors’ E-Mail Addresses: santoshin@imf.org, marena@imf.org, ngueorguiev@imf.org, tlybek@imf.org,jralyea@imf.org, eyehoue@imf.org

\footnotetext{
${ }^{1}$ We would like to thank Qianying Chen, Seung Mo Choi, Jorg Decressin, Michael Gorbanyov, Gee Hee Hong, Mehdi Raissi, Anke Weber, S. Reza Yousefi, and the participants in seminars in Austria, Croatia, Iceland, and Slovenia for helpful comments. All errors and omissions are our own.
} 


\section{TABLE OF CONTENTS}

Abstract _ $2 \underline{2}$

I. Introduction

II. Post-GFC Economic Developments in Europe: Different from Past Recoveries? __ 7

III. Credit Growth and Economic Activity ___

IV. Financial and Macroeconomic Indicators Influencing Credit Growth ___ 24

V. Credit Growth and Bank Profitability ___ 26

VI. Summary of Main Findings ___ 29

\section{FIGURES}

1. EUR economies pre- and post-GFC outturns ___ $\underline{8}$

2. Non-financial Episodes: Recession and Recovery Period ___ 15

3. Financial episodes: Recession and Recovery Period __ 16

4. Non-financial Episodes: Breakdown by Exchange Rate Regime___

5. Financial Episodes: Breakdown by Exchange Rate Regime ___

\section{TABLES}

2.1 Cyclical properties of real output and real bank credit to the private sector $\_\underline{9}$

2.2 External demand comparison __

3.1 Regressions using lending standards-based instruments ___ 22

3.2 Credit Growth and GDP Growth __

3.3 Credit Growth and Private Investment Growth __

3.4 Credit Growth (total credit) and GDP Growth __

3.5 Credit Impulse and GDP Growth ___ _

4.1. Cross-Country Analysis of Determinants of Credit Growth: Regression Results ___ $\underline{35}$

5.1. Models for Bank Profitability and Credit Growth ___

5.2. Models for Bank Profitability and Credit Growth___ 37

\section{APPENDICES}

I. Economic Hypotheses about Post-Financial-Crisis Recoveries ___ $\underline{38}$

II: Selected Data Issues __ 41

A. Countries and Period Covered ___

B. Data Sources___

C. Data Cleaning__

D. Selected Definitions and Concepts
ANNEXES
II.1. Description of Data used in Section II
II.2. Description of Data used in Section III
II.3. Description of Data used in Section IV
$\underline{46}$
II.4. Description of Data used in Section V 


\title{
I. INTRODUCTION
}

\begin{abstract}
Almost a decade after the global financial crisis (GFC) in 2008, economic activity and bank lending in Europe have yet to fully recover, the recent pick-up notwithstanding. In many countries, real GDP has grown slower than in other post-recession recoveries and unemployment has remained elevated. Estimates of potential growth have dropped notably relative to the early 2000 s, largely due to lower investment and declining total factor productivity growth. ${ }^{2}$ Credit extension is recovering only slowly, despite historically low lending interest rates, constrained by over-indebted firms and households.
\end{abstract}

\section{Numerous studies have documented that recoveries after financial crises-particularly after credit fueled booms and busts - are often weak and sluggish. Economic theory has} long recognized that recoveries from financial boom-bust episodes are weaker and take longer than other recoveries as borrowers and lenders' over-leveraged balance sheets need time to adjust (Appendix I). Political economy issues also come into play. ${ }^{3}$ On the empirical side, IMF (2008, 2009A and 2009B) and Bordo and Haubrich (2009) find that financial distress typically exacerbates the economic slowdown, while Coricelli et al. (2011) discuss how credit conditions influence recoveries. Claessens, Kose and Terrones (2009A and 2011) conclude that: “... recessions accompanied by financial disruption episodes, notably house price busts, tend to be longer and deeper while recoveries combined with rapid growth in credit and house prices tend to be stronger." Jordà et al. (2013A) argue that financial indicators, like credit, tends to amplify the business cycle, and (in Jordà et al., 2014) that the recovery path is even worse when the credit-fueled crisis coincides with elevated public debt. Taylor (2015) finds that one in four recessions are caused by financial crises and that these recessions are deeper and longer, with inflation subdued and credit recovery slow. ${ }^{4}$ Caselli, Greenberg, and Scott (forthcoming) confirm that the contraction phase has been longer and the recoveries weaker after the GFC.

Many empirical studies have also found that credit extension has been slow to rebound after financial crises, giving rise to creditless recoveries. The term creditless recovery is often attributed to Calvo, Izquierdo and Talvi (2006A, 2006B) and Claessens et al. (2009A and 2009B). Abiad, Dell'Ariccia, and Li (2011) find that about one in five recoveries in the period 1964-2007 has been creditless and weaker than normal recoveries. Bijsterbosch and

\footnotetext{
${ }^{2}$ For recent analyses of the effect of credit-fueled booms and busts on potential output and employment, see, among others, Blanchard et al. (2015), Berger et al. (2015), Podpiera et al. (2017).

${ }^{3}$ Cerra and Saxena (2008) argue that recouping lost output after a deep financial crisis is a myth, in part because economic crises intensify political tensions. This is corroborated by Funke et al. (2016), who find that, in contrast to non-financial recessions, polarization tends to rise and government support to shrink after systemic banking crises. They argue that this creates gridlock and policy uncertainty that may slow recoveries after financial crises.

${ }^{4}$ Takáts and Upper (2013) find - examining the outcome of 39 financial crises - that bank credit is significantly positively correlated with real growth only in the third and fourth year of the recovery. They also find that improved competitiveness via exchange rate depreciations are more important for faster recoveries after a financial crisis than credit growth. In contrast, Bech et al. (2012) argue that that deleveraging will ultimately lead to stronger recoveries.
} 
Dahlhaus (2011) also find that the incidence of creditless recoveries doubles after a banking or currency crisis, and that these recoveries are weaker when major balance sheet readjustment is needed after a shock. Sugawara and Zalduendo (2013) find that about 25 percent of all recoveries are creditless, and that this share increased to 45 percent after the GFC. Bodnár et al (2014) find that between a quarter and a fifth of recoveries are creditless and real growth is permanently lower during such recoveries. However, Biggs et al. (2009) argue that creditless recoveries are an artefact of methodology: most of these studies compare growth in real GDP (a flow) with growth in credit (a stock), while the proper comparison should be between the change in the credit flow — the credit impulse - and real GDP growth.

\section{Balance sheet recessions may be more severe and more likely to be followed by creditless recoveries due to the necessary restructuring of private balance sheets. ${ }^{5}$ IMF} (2013) found that factors such as the build-up of excessive debt by households and firms and excessive leverage (shortage of capital) in banks have restricted credit flows in European and other economies after the GFC. High borrower debt restricts demand for credit and reduces borrowers' creditworthiness, while thin bank capital cushions reduce the banks' willingness and ability to lend. Everaert et al. (2015) analyze demand and supply of credit in selected Central, Eastern, and Southeastern European (CESEE) countries before and after the GFC. They find that the importance of demand and supply factors vary widely between countries. IMF (2015B) notes that recoveries in many CESEE countries were held back by weak corporate and household balance sheets. Gaspar et al. (2016) argue that a successful restart of credit flows calls for a concerted policy package that relieves the binding constraints on credit extension, often in a complementary manner.

\section{This paper reviews the empirical relationships between credit growth, economic} recovery, and bank profitability in Europe after the GFC. Specifically, it aims to address the following questions:

- How have the post-GFC economic and credit dynamics in Europe evolved? How do they compare to recoveries from previous recessions and financial crises?

- How has credit extension related to economic activity in Europe? Has the relationship changed after the GFC?

- Which financial and macroeconomic indicators have been most closely correlated with credit dynamics?

- How has bank profitability, an important indicator of financial soundness, been affected by credit developments?

\footnotetext{
${ }^{5}$ The term balance sheet recession is often ascribed to Koo (2003 and 2011). Bakker and Lipschitz (2014) distinguish between conventional balance sheet recessions, which are triggered by external imbalances and sudden stop of capital inflows, and insidious balance sheet recessions, mainly triggered by internal imbalances, like a housing bubble.
} 
Compared to previous work in this field, this paper benefits from an expanded sample and more recent data. ${ }^{6}$ The data panel is richer than those used in previous studies, which permits the use of econometric tools that alleviate some difficult econometric challenges. Specifically, our sample includes annual data for 1999-2016 (2015 for bank-level data), starting with the introduction of the euro, for 39 European countries in most of the analysis. We use the generalized methods of moments (GMM) estimator, which helps mitigate endogeneity issues, while the larger data set alleviates multicollinearity challenges. We also use data back to 1972 for a group of advanced and emerging market economies to estimate the expected recession and recovery path for groups of European countries.

\section{Our findings reveal that the post-GFC recoveries in Europe have been weaker than previous recoveries, a result explained by the "double-dip" recessions in 2011-12 in} many European countries and the worldwide reach of the GFC. Bank credit extension in the post-GFC period has been sluggish as well, but this appears to have affected the recovery relatively moderately. A 10 percent increase in bank credit to the private sector is associated with a rise of $0.6-1$ percent in real GDP growth and 2-2 $\frac{1}{2}$ percent in real private investment growth. These relationships have not changed significantly during and after the GFC overall, but we found evidence of creditless recoveries in countries that had experienced a credit boom prior to the GFC. Loan quality, customer deposits, and the bank equity price index appear to be closely linked to bank credit. Bank profitability has been positively and significantly influenced by credit growth both before and after the GFC, but this relationship appears to have broken during the GFC-induced recession.

The rest of the paper is organized as follows. Section II analyzes the post-GFC patterns of economic activity and bank credit in Europe compared to previous conventional and financial crisis-driven recessions. Section III studies the interactions between credit growth and economic performance indicators (real GDP growth and real private investment). Section IV identifies bank specific and macroeconomic factors most closely correlated with credit growth. In Section V, we look at the relationship between credit growth and bank profitability. Section VI summarizes our findings. Appendix I provides a brief overview of various economic hypotheses about post-financial crisis recoveries. Appendix II describes the data and sources.

\footnotetext{
${ }^{6}$ This paper also served as the background note for several case studies: Austria (Chapter II in IMF Country Report No. 17/27); Croatia (forthcoming); Hungary (Chapter I in IMF Country Report No. 17/124); Iceland (Chapter II in IMF Country Report No. 17/164); and Slovenia (Chapter I in IMF Country Report No. 17/126).
} 


\title{
II. Post-GFC ECONOMIC DEVELOPMENTS IN EUROPE: DifFERENT FROM PAST RECOVERIES?
}

\section{A. The European Business and Credit Cycle Since 1999}

\begin{abstract}
A long expansion, followed by a deep recession and a slow recovery characterize the European business cycle since 1999 (Figure 1). ${ }^{7}$ Three distinct phases can be identified: gradual acceleration and boom (1999-08), bust (2009-11), and a sluggish recovery (2012-16), though important differences exist among countries. For many advanced European countries, joining the euro area significantly reduced financing costs, which contributed to a credit, investment, and consumption pick-up that prolonged and accentuated the growth phase of their cycle. CESEE countries had the highest average growth in Europe over the 1999-2008 period, reflecting optimism about their economic convergence prospects.
\end{abstract}

The global financial crisis hit both advanced and emerging European economies. On average, output contracted about $7 \frac{1}{2}$ percent (unweighted) in the 35 European countries that experienced a recession in 2008-09. Recovery speeds have varied. CESEE countries have resumed their relatively more robust growth pattern, though at more subdued levels than before the crisis. Growth in non-euro area advanced European countries has picked up sooner than in advanced euro area countries, some of which experienced a second recession in 2011-12.

Bank credit has followed a similar pattern to economic growth within the country groupings. Bank credit grew rapidly in many European countries in the run up to the crisis. After the crisis, bank lending fell most in advanced euro area economies, but the difference from the pre-crisis trend is largest in CESEE countries (Figure 1). On average, bank credit to GDP in the European Union remains about 10 percent below its pre-GFC peak level.

\section{B. Is the post-GFC experience in Europe different from previous boom/bust periods?}

We conduct an empirical analysis to assess the speed and extent of the post-GFC recovery in Europe relative to other similar episodes. Following Jordà, Schularick, and Taylor (2013), we develop an empirical model of post-expansion peak recession and recovery paths for key macroeconomic variables based on a core sample of countries' experiences. The peaks in economic activity and the associated recession and recovery episodes are divided into two buckets: conventional versus those following a financial sector boom/bust pattern. An empirical model was used to develop expected recovery paths ("projection paths") after the start of a recession for the following macroeconomic variables: real GDP per capita, real private consumption per capita, real investment per capita, real bank credit per capita (deflated by the consumer price index) to the non-financial private sector, and the current account balance.

\footnotetext{
${ }^{7}$ The analysis starts with the creation of the euro area, which sharply raised the intensity of financial flows in Europe.
} 


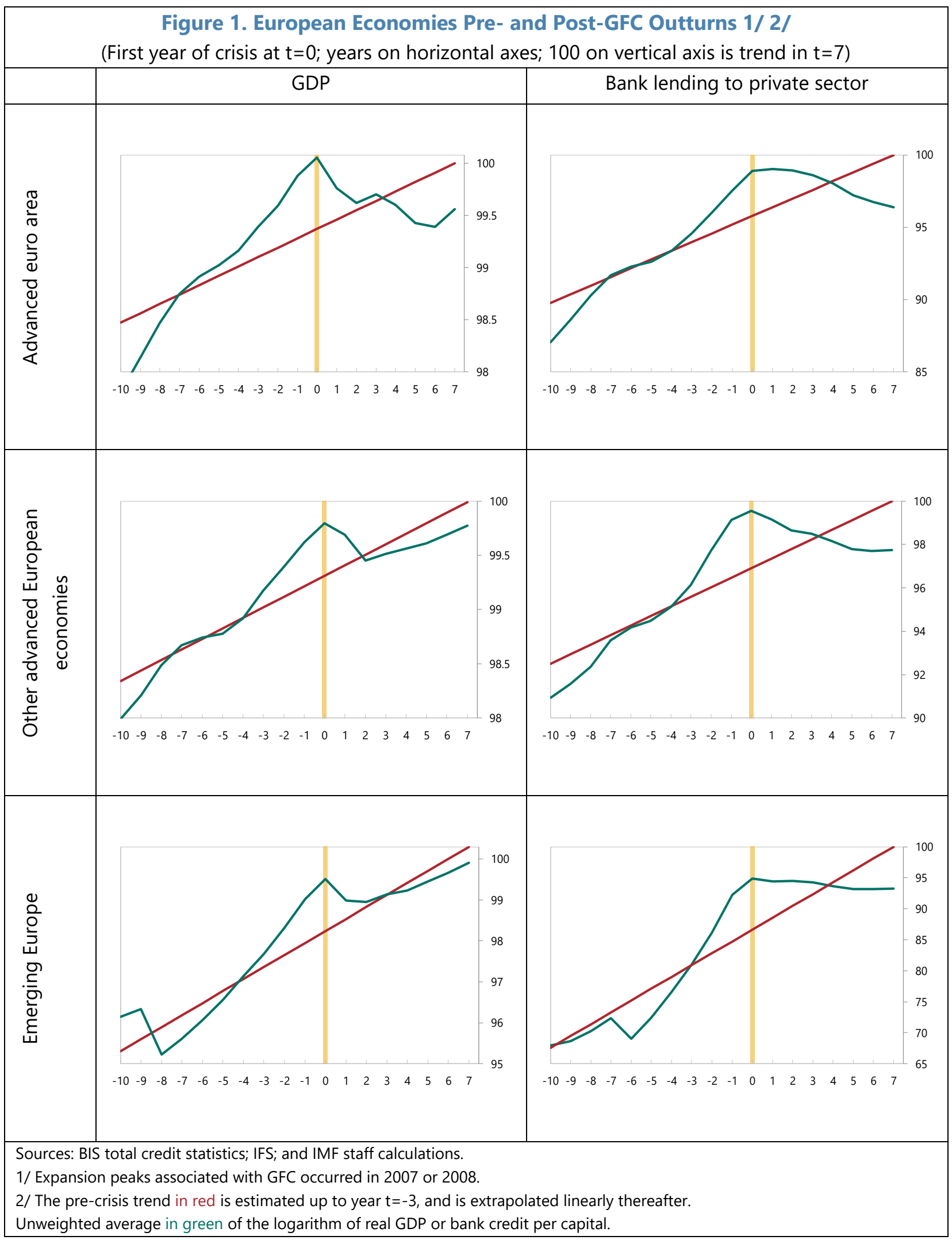


Advanced countries and major emerging market economies that experienced a recession in the post-Bretton Woods period (1972-2006) constitute the control group in our analysis. These 37 countries, including 21 European countries, experienced 116 conventional and 28 financial business cycle peaks. ${ }^{8}$ The economic expansions preceding each peak and the five-to-seven-year horizon afterwards (depending on data availability) constitute the observation episodes in the regression sample. We use the Bry and Boschan (1971) algorithm to date the business cycle peaks and troughs across countries. Recessions were classified as conventional or financial based on the definition of systemic banking crisis in Laeven and Valencia (2012) (see Appendix II, Section D).

The expansions in advanced European countries preceding the GFC were longer and stronger than a typical post-Bretton Woods expansion. In 2007-08, 20 advanced European countries reached business cycle peaks. The expansions leading to these peaks were longer by about 6-9 years - and the cumulative change in real GDP per capita was 5-12 percentage points greater than business cycles with peaks during 1972-2006.

Interestingly, real credit per capita expanded about 35 percent in the euro area countries, not far from other post-Bretton Woods expansions. Bank credit dynamics in non-euro advanced European countries were considerably more volatile both pre- and post-GFC (Table 2.1).

\begin{tabular}{|c|c|c|c|c|c|c|c|c|c|c|}
\hline & \multicolumn{5}{|c|}{ Real GDP per capita } & \multicolumn{5}{|c|}{ Real bank credit per capita } \\
\hline & \multirow{3}{*}{$\begin{array}{l}\text { Non - } \\
\text { European } \\
\text { countries }\end{array}$} & \multicolumn{4}{|c|}{ Advanced European countries } & \multirow{3}{*}{$\begin{array}{c}\text { Non - } \\
\text { European } \\
\text { countries }\end{array}$} & \multicolumn{4}{|c|}{ Advanced European countries } \\
\hline & & \multicolumn{2}{|c|}{ Euro area } & \multicolumn{2}{|c|}{ Non-Euro area } & & \multicolumn{2}{|c|}{ Euro area } & \multicolumn{2}{|c|}{ Non-Euro area } \\
\hline & & $1972-06$ & GFC 3/ & $1972-06$ & GFC 3/ & & $1972-06$ & GFC 3/ & $1972-06$ & GFC 3/ \\
\hline \multicolumn{11}{|l|}{ Amplitude 2/ } \\
\hline Expansion & 14.1 & 22.2 & 27.1 & 16.8 & 29.1 & 15.7 & 30.3 & 35.5 & 19.7 & 72.2 \\
\hline Recession & -3.8 & -1.1 & -4.2 & -1.7 & -6.8 & -4.6 & -0.2 & -1.0 & 1.0 & -3.6 \\
\hline \multicolumn{11}{|c|}{ Annual average rate } \\
\hline Expansion & 3.4 & 2.9 & 2.1 & 2.9 & 2.3 & 5.0 & 5.3 & 6.0 & 4.3 & 4.5 \\
\hline Recession & -2.5 & -1.1 & -3.6 & -1.0 & -3.4 & -3.5 & -0.2 & -1.0 & 0.5 & -1.8 \\
\hline \multicolumn{11}{|c|}{ Duration (years) } \\
\hline Expansion & 4.0 & 8.0 & 14.0 & 5.0 & 14.0 & 4.0 & 8.0 & 14.0 & 5.0 & 14.0 \\
\hline Recession & 1.0 & 1.0 & 2.0 & 1.0 & 2.0 & 1.0 & 1.0 & 2.0 & 1.0 & 2.0 \\
\hline \multicolumn{11}{|c|}{ Sources: BIS total credit database; IMF WEO and IFS databases; and IMF staff calculations. } \\
\hline \multicolumn{11}{|c|}{$1 /$ Table elements are the medians of the referenced statistic for the cycle episodes in that country grouping. } \\
\hline \multicolumn{11}{|c|}{ 2/ Amplitude is cumulative peak to trough (recession) and trough to peak (expansion) change. } \\
\hline 3/ Averages pr & ansion) a & ollowing $(r$ & (cession) p & levels atta & a & & risis. & & & \\
\hline
\end{tabular}

\section{Deriving Projected Recession/Recovery Paths}

We derive recovery paths for analyzing the post-GFC outturns in Europe using the local projections method of Jordà (2005). Local projections allow for the development of impulse response functions that account for the effects of pre-recession credit expansion and financial crisis, two hallmarks of the post-GFC recession in Europe, on the conditional forecast paths (recovery paths) of key macroeconomic variables. To do this, indicators were

\footnotetext{
${ }^{8}$ Missing data reduced the number of episodes in the empirical analysis to 83 (68 conventional and 15 financial episodes).
} 
introduced to split the sample into episodes following a conventional (non-financial) expansion peak and those following a financial peak accompanied by a banking crisis. In addition, these indicators were interacted with a measure of the pace of bank lending that preceded the recession to control for the effects of the pre-recession credit accumulation.

The impulse responses represent the cumulated response at each horizon for each variable of interest. The regressions control for country-specific effects by including country dummies and other relevant macroeconomic variables. Specifically, the following model was used:

$\Delta_{h} y_{i t(r)+h}^{k}=\propto_{i}^{k}+\emptyset_{h} N_{i t(r)}+\gamma_{h} F_{i t(r)}+\varphi_{h} N_{i t(r)} *\left(x_{i t(r)}-\overline{x_{N}}\right)+\theta_{h} F_{i t(r)} *$
$\left(x_{i t(r)}-\overline{x_{F}}\right)+\sum_{j=0}^{p} \beta_{j}^{k} Y_{i t(r)-j}+e_{i t(r)}^{k}$

Intuitively, the coefficients $\emptyset$ and $\gamma$ reflect the average cumulative response of the dependent variable at each horizon (projection) period. The values of the control variables used in the regressions are their values in the peak year (start of the $r_{\text {th }}$ recession) and one period prior.

\section{Europe's Post-GFC Economic Performance}

The assessment of Europe's post-GFC experience was conducted in four parts (Figures 2-5). We start by comparing the "standard" projection paths to actual economic outturns in Europe since the onset of the GFC-induced recessions. We then investigate two factors that may have been responsible for Europe's relatively slow recovery - the worldwide nature of the GFC and the 2011-12 European sovereign debt crisis. In contrast to most pre-GFC recessions, which were confined to individual countries or at most regions, the GFC precipitated a worldwide recession. This may have affected the speed and vigor of the subsequent recovery, as countries could not rely on robust external demand to support their growth. To assess the impact of this effect on Europe's post-GFC recovery, we construct counterfactual recovery paths for the control group based on the external demand patterns faced by European countries after the GFC and compare Europe's post-GFC performance to these adjusted paths. Next, we also compare the adjusted projection paths to economic outturns in Europe following the 2011-12 euro area sovereign debt crisis, to test the hypothesis that the double-dip recessions in many countries caused by the sovereign debt crisis are responsible for the observed weak overall recovery. Finally, we explore the possible influence of European countries' exchange rate regimes on the relative pace of economic recovery in the post-GFC era. 
Conventional (non-financial) recessions

European economies that did not experience a financial crisis in 2008/09 performed starkly worse than expected after the GFC (Figure 2, left column). All country groups had much deeper and longer recessions relative to previous recession episodes in the postBretton Woods period.

- In the advanced euro area countries, real GDP, consumption, and investment (all per capita) just (broadly) returned to their pre-GFC levels by 2015, seven years after the GFC. The double-dip pattern in real GDP and consumption, as well as the large and protracted drop in investment, make their performance radically different from the average pre-GFC crisis recovery pattern.

- Advanced non-euro area countries perform qualitatively similarly to the projection path, but the recovery in real GDP, consumption, and (recently) investment was much slower than in pre-GFC recoveries.

- The distinctive feature of the CESEE recession-recovery pattern is the very sharp initial drop in GDP, consumption, and (especially) investment, mirrored by an unprecedented adjustment in the current account balance. Once the recovery in this group got under way, it proceeded apace with the pre-GFC recoveries in terms of speed, but the levels of real GDP, consumption, and investment remain significantly below those implied by historic recovery patterns.

- Despite the large differences in economic performance between the three country groups, credit extension was almost equally subdued. The credit stock remained essentially flat relative to the admittedly high pre-GFC level, suggesting a limited role for credit in explaining the post-GFC economic dynamics.

\section{The worldwide downturn following the GFC explains only a small fraction of the dampened post-GFC recovery in Europe in countries with conventional recessions} (Figure 2, middle column). This global downturn (Kose and Terrones, 2015) generated significantly weaker trading partner demand for European exports than the demand experienced by countries that had recessions prior to 2007 (the control group). To control for this factor, the blue lines in the middle column in Figure 2 show counterfactual expected recovery paths for the control group that are projected using the average post-GFC external demand path faced by European countries (shown in Table 2.2). ${ }^{9}$ Surprisingly, this correction did not result in notably different expected paths of real GDP per capita and private

\footnotetext{
${ }^{9}$ These counterfactual paths are generated as follows: (i) a contemporaneous actual-data external demand variable is included in the original regressions to estimate its influence on the projection paths experienced by the control group; (ii) this external demand variable is then rescaled to reflect, on average, the external demand faced by European countries after the GFC (the column "Europe post-GFC" in Table 2.2); (iii) new counterfactual dependent variables are generated using the regressions in (i) and the rescaled external demand variable in (ii), representing "what-if" estimates of these variables had the control group countries faced the same subdued external demand that European countries faced post-GFC; and (iv) the original regressions are re-run with the new counterfactual dependent variables.
} 
consumption relative to the left column in Figure 2. The expected path for investment and bank lending declined moderately only late in the projection period (in 2014-15), implying that the weaker global conditions faced by European countries explain at best a small portion of the economic underperformance late in the analyzed period. One reason for this finding could be that openness has likely increased over time, so that the estimated coefficients measuring the influence of external demand on domestic economic performance in the control group in 1972-2006 may understate the true post-2008 effect.

\begin{tabular}{|c|c|c|c|c|c|c|}
\hline \multicolumn{7}{|c|}{ Table 2.2 External Demand Comparison ${ }^{1 /}$} \\
\hline \multirow[b]{2}{*}{ Horizon year } & \multicolumn{2}{|c|}{ Number of episodes } & \multicolumn{4}{|c|}{ Cumulative average growth Difference } \\
\hline & \multirow[t]{2}{*}{$\begin{array}{l}\text { Control } \\
\text { group }\end{array}$} & $\begin{array}{l}\text { Europe } \\
\text { post-GFC } \\
2 /\end{array}$ & $\begin{array}{l}\text { Control } \\
\text { group }\end{array}$ & $\begin{array}{l}\text { Europe } \\
\text { post-GFC } \\
2 /\end{array}$ & (p.p.) & \\
\hline \multicolumn{6}{|c|}{ Non-financial } & \\
\hline 1 & 94 & 48 & 3.7 & -3.8 & 7.5 & $-\star \star \star *$ \\
\hline 2 & 94 & 48 & 9.8 & -0.5 & 10.3 & $\star \star \star *$ \\
\hline 3 & 94 & 46 & 17.7 & 4.6 & 13.0 & *** \\
\hline 4 & 94 & 45 & 26.1 & 7.3 & 18.7 & *** \\
\hline 5 & 94 & 43 & 36.7 & 9.9 & 26.8 & $\star \star * *$ \\
\hline 6 & 94 & 28 & 47.2 & 11.1 & 36.1 & $\star \star * \star$ \\
\hline 7 & 94 & 25 & 58.1 & 13.4 & 44.7 & $\star \star \star *$ \\
\hline \multicolumn{7}{|c|}{ Financial } \\
\hline 1 & 32 & 12 & 5.4 & -0.6 & 6.0 & $\star \star \star$ \\
\hline 2 & 32 & 12 & 13.8 & -5.8 & 19.6 & $\star \star \star *$ \\
\hline 3 & 32 & 12 & 23.1 & 2.7 & 20.4 & $\star \star *$ \\
\hline 4 & 32 & 12 & 28.9 & 7.3 & 21.6 & $\star \star \star *$ \\
\hline 5 & 32 & 12 & 38.6 & 9.9 & 28.6 & $* * *$ \\
\hline 6 & 32 & 11 & 52.0 & 13.1 & 38.9 & $\star \star * *$ \\
\hline 7 & 32 & 11 & 65.6 & 17.1 & 48.6 & $\star * \star$ \\
\hline \multicolumn{7}{|c|}{ Sources: WEO; IMF staff calculations } \\
\hline \multicolumn{7}{|c|}{$\begin{array}{l}\text { 1/ Cumulative external demand growth experienced, on average, by the countries in the } \\
\text { control group (with recessions before } 2007 \text { ) and European countries after the start of the } \\
2 / \text { Number of episodes exceeds the number of EU countries because several countries had } \\
\text { multiple recession and recovery periods post-2007, i.e., "double-dip recessions." }\end{array}$} \\
\hline \multicolumn{7}{|c|}{ T-test for significance of difference: $* *<5$ percent; ${ }^{* \star *}<0.1$ percent } \\
\hline
\end{tabular}

\section{In contrast, the euro area sovereign debt crisis in 2011-12 does help explain a large part} of Europe's weak recovery from post-GFC non-financial recessions (Figure 2, right column). The resulting "double-dip" recession in many countries could be viewed as a continuation of the GFC-induced recession rather than a separate one. To account for that, the right column in Figure 2 presents results when the pre-recession expansion peak is timed in $2011 .{ }^{10}$ Now all analyzed variables in CESEE countries tend to be within or close to the projection path confidence band. The performance of the advanced non-euro area countries is similar, except that real GDP per capita underperforms late in the projection horizon despite earlier overperformance of investment and lending. However, the recovery in the advanced euro area countries remains delayed and subdued, the pick-up in years 4-5 notwithstanding. Lending underperforms again in advanced euro area economies and CESEE countries. As

\footnotetext{
${ }^{10}$ Although the euro are sovereign debt challenges were already present in late 2011, this year was chosen as the peak prior to the subsequent recession given that 16 of the 21 European countries that saw a "double dip" recession experienced local GDP peaks in 2011. This column also controls for the subdued external demand as explained above.
} 
these two groups are at opposite ends of the economic performance spectrum, this is another indication that credit has been only loosely connected with economic dynamics post-GFC.

\section{Financial recessions}

\section{European countries that experienced banking crises also underperformed historical} patterns (Figure 3, left column). In advanced euro area countries that had a banking crisis during or after the GFC, real GDP, consumption, and investment remained significantly below the projection path and the pre-crisis levels even seven years after the GFC. Advanced non-euro area economies also underperformed the projection path (and the advanced euro area countries in this group) over the whole projection horizon. ${ }^{11}$ Interestingly, the cumulative real lending for all European countries that experienced a banking crisis in 2008-9 was broadly in line with the (admittedly weak) derived projection path.

In contrast to the conventional recession cases, the worldwide reach of the GFC notably affected the recovery of European countries that had banking crises (Figure 3, middle column). Performing the counterfactual exercise described above brings the expected recovery paths closer to the observed ones for all variables and countries. Yet this adjustment is not sufficient to fully explain the weaker than expected European recoveries, especially in the early part of the period. Bank lending performs weakly as expected in advanced non-euro area economies, but better than expected in the advanced euro area countries. This may reflect the aggressive monetary easing and liquidity provision policies of the ECB during the recovery period.

As in the case of conventional recessions, starting the count from the euro area sovereign debt crisis does change the picture considerably (Figure 3, right column). Most striking is the strong overperformance of investment and (to a lesser extent) consumption in all country groups relative to the projection path. This combination results in overperformance of real GDP as well. Again, and in line with the pre-GFC pattern of recovery from financial crises, credit dynamics remain very subdued, not visibly contributing to the broader economic recovery.

\footnotetext{
${ }^{11}$ The lines for CESEE countries in Figure 3 reflect mainly the experience of Latvia, with a very sharp drop in real GDP, consumption, and investment, followed by a vigorous recovery.
} 
Fixed versus floating exchange rate regime ${ }^{12}$

European countries with more flexible exchange rates performed similarly to those with less flexible ones in the group of countries that endured non-financial recessions (Figure 4). Controlling for differences in external demand and the euro area sovereign debt crisis (the rightmost column in Figure 4) indicates that floaters performed better in the early stages of the recession/recovery period, while non-floaters caught on late in the projection horizon. The relative performance of floaters and non-floaters likely reflects the slower adjustment of variables such as real wages and prices in the absence of exchange rate flexibility. Both floater and non-floater recoveries in real GDP and consumption are broadly in line with the typical post-Bretton Woods experience once relevant controls are introduced. However, it is noteworthy that investment in both groups overperforms historic patterns, while credit significantly underperforms. This suggests that companies have found non-bank sources of investment financing. ${ }^{13}$

Floaters show better performance in some indicators than non-floaters among countries that had banking crisis during and after the GFC (Figure 5). With the relevant controls, the recovery in real GDP, consumption, and investment is stronger in floaters after the euro area sovereign debt crisis (the rightmost column in Figure 5). However, one should not read too much into these relative outcomes. The sample of floaters that had financial crisis is very small - the United Kingdom and Iceland - and Iceland had a strong recovery but only after a very deep banking crisis. More importantly, both floaters and non-floaters compare favorably, when controlling for differences in external demand and the euro area sovereign debt crisis, to the typical recession and recovery path experienced by control group countries that had a financial crisis. This suggests that policies to contain and resolve the financial crises may have worked better in the European countries on average than in the group of countries that had financial crises in 1972-2006. Again, investment overperforms the historical pattern despite the weak performance of credit, indicating the presence of non-bank forms of financing.

\footnotetext{
${ }^{12}$ European countries were split into two groups - floaters and non-floaters - based primarily on their exchange rate classification for 2008 in the IMF's Annual Report on Exchange Arrangements and Exchange Restrictions (AREAER).

${ }^{13}$ To some extent, the strong performance of investment is also supported by the EU structural and cohesion funds in some members of the European Union.
} 


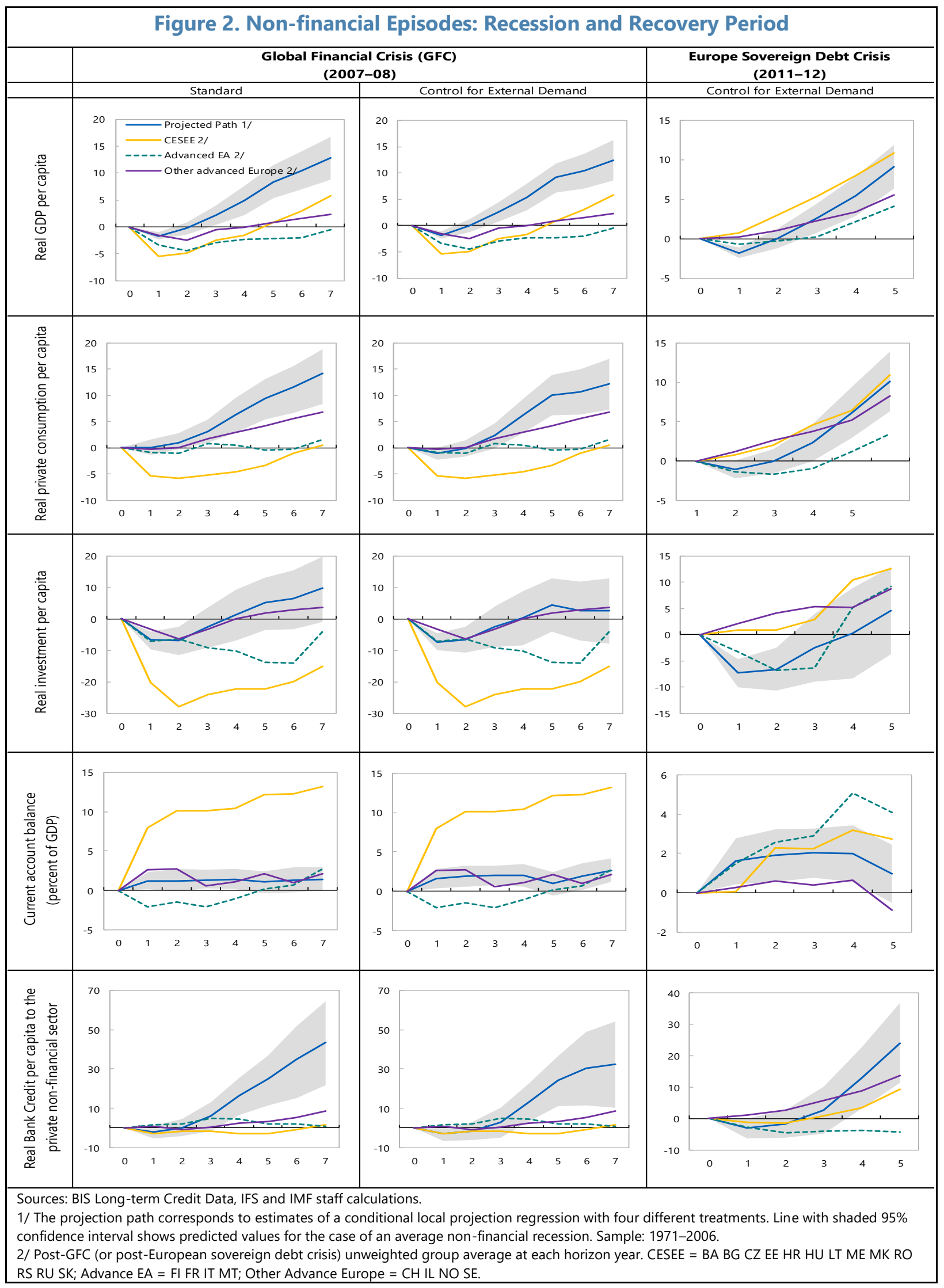

CInternational Monetary Fund. Not for Redistribution 


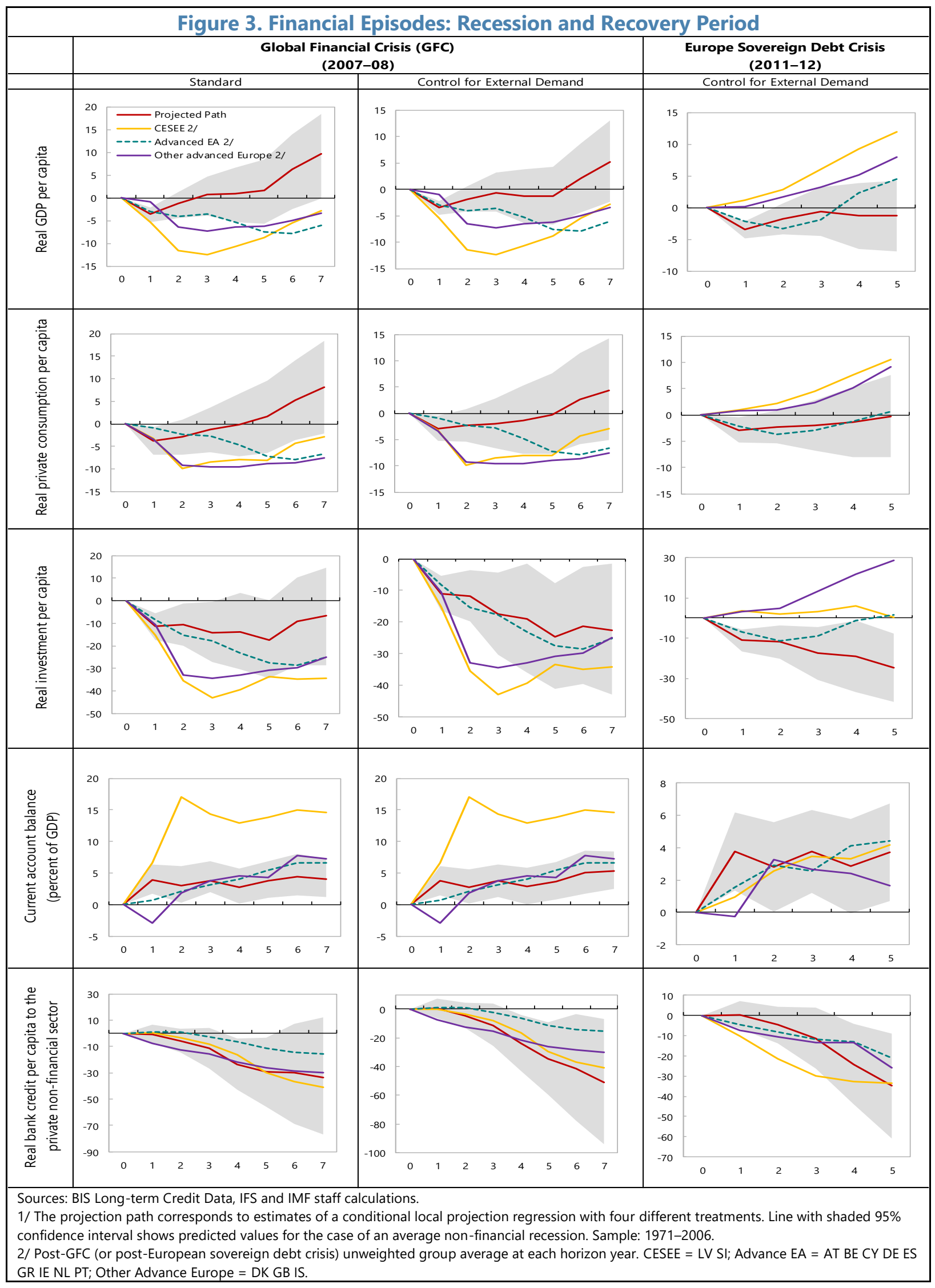

CInternational Monetary Fund. Not for Redistribution 


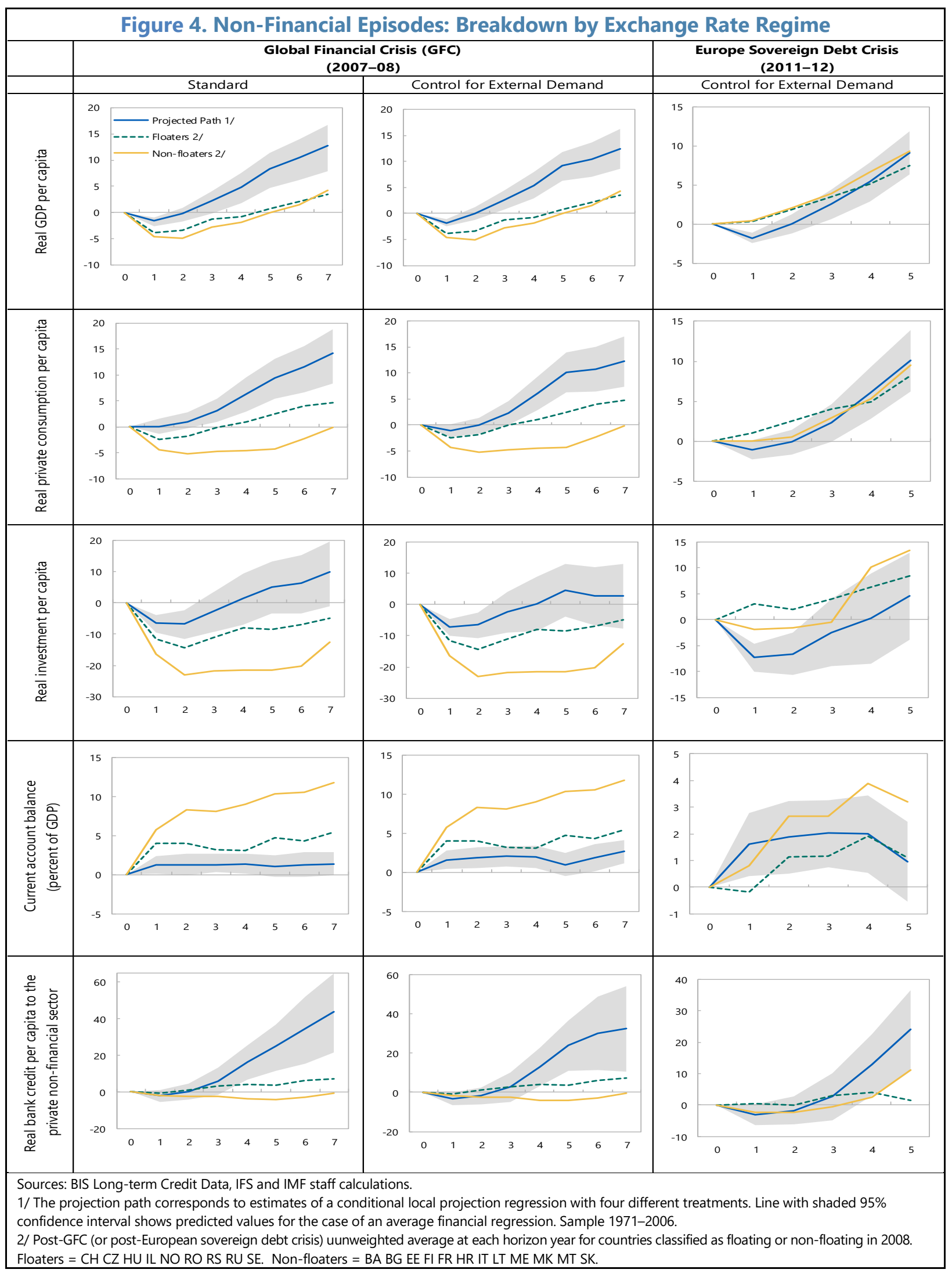

CInternational Monetary Fund. Not for Redistribution 


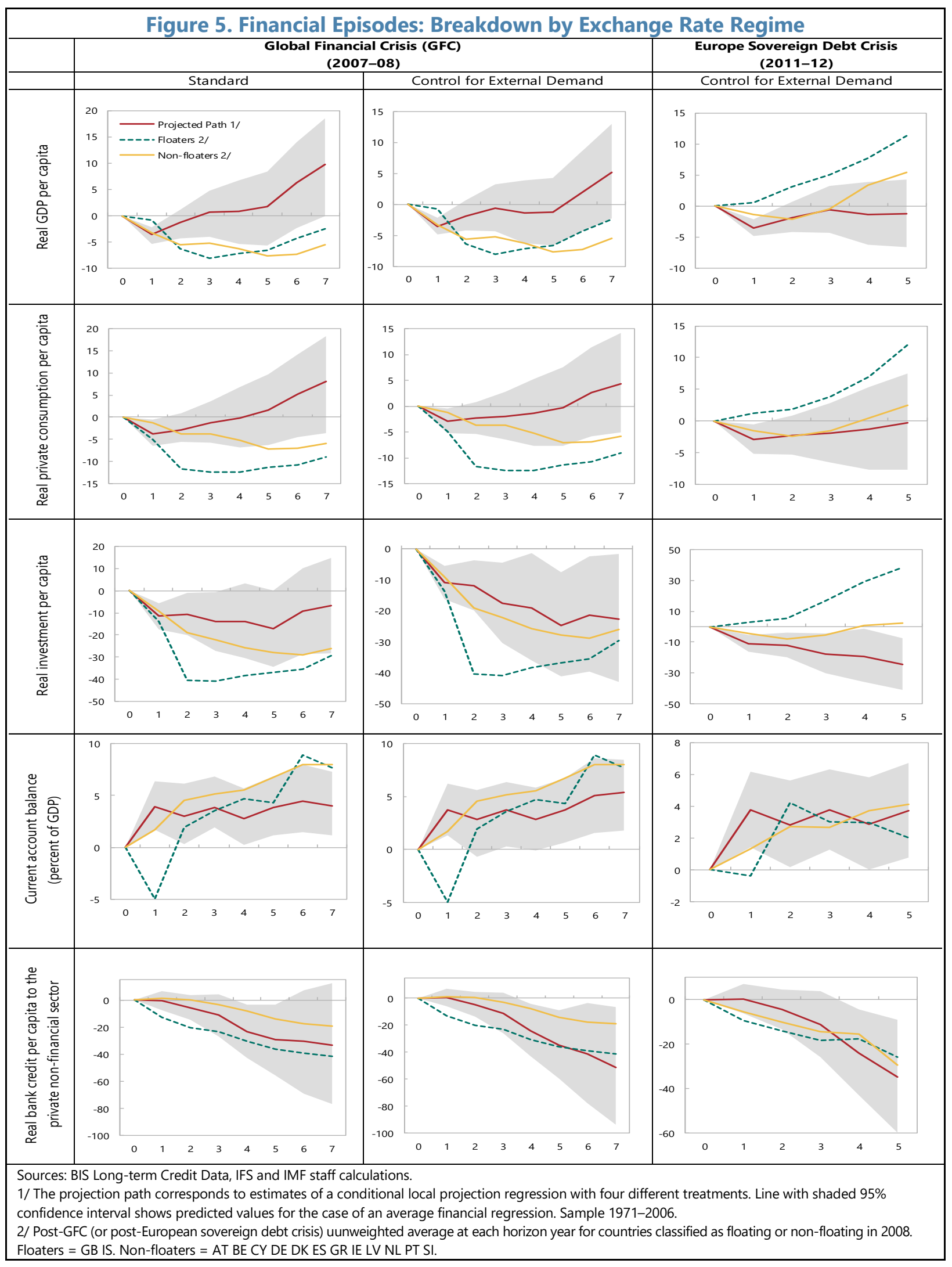

CInternational Monetary Fund. Not for Redistribution 


\section{Credit Growth ANd Economic ACTIVITY}

How important is credit growth for economic activity in Europe? The financial development literature points to the importance of credit for supporting economic growth, at least up to a point. ${ }^{14}$ Moreover, the creditless recovery literature does point out that creditless recoveries are usually shallower than normal ones (see Section I for references). However, our analysis in Section II suggests that the post-GFC GDP and investment recovery often coexisted with subdued bank lending. This section therefore aims to estimate the empirical relationship between credit extension and measures of economic activity like GDP and investment growth, as well as to check whether this relationship has changed after the GFC.

We use a dynamic system GMM panel estimator (Blundell and Bond, 1998) to estimate the relationship between credit growth, GDP growth, and private investment growth. ${ }^{15}$ Given that the estimation period only covers one complete business cycle, we control for variables that capture relevant information at the business cycle frequency as opposed to a long-run relationship. In the case of GDP growth, these variables include public consumption, trading partners' external demand, and the VIX volatility index as a proxy for global influences on GDP growth. In addition, we include the ratio of bank credit to the private sector to GDP to control for potential negative short-run effects of previous lending. ${ }^{16}$ We thus use the following specification:

$$
\begin{aligned}
\text { Growth }_{i t}= & \alpha_{i}+\alpha_{1} \text { Growth }_{i t-1}+\alpha_{2} \text { Credit }_{i t}+\alpha_{3} \text { Pubcons }_{i t}+\alpha_{4} \text { CreditGDP }_{i t} \\
& +\alpha_{5} \text { Extdem }_{i t}+\alpha_{6} \text { VIX }_{t}+\varepsilon_{i t}
\end{aligned}
$$

The letters $i$ and $t$ refers to country and time (in years), Growth is the growth rate of real GDP, Credit is the growth rate of bank credit to the private sector (change in stocks) in real terms, Pubcons is the growth rate of public consumption in real terms, CreditGDP is the ratio of bank credit to the private sector to GDP, Extdem is the growth rate of trading partners' external demand, and VIX is the log of the VIX index. We also include dummies for the postGFC recession and recovery periods and interact them with the credit growth variable to check for structural breaks in the relationship between credit growth and GDP growth.

For the estimation of private investment growth, following Spatafora and Luca (2012), we include additional control variables. They include a measure of macroeconomic stability (the general government balance as a ratio to GDP) and a measure of the cost of

\footnotetext{
${ }^{14}$ For instance, Beck and Levine (2000), Beck, Levine, and Loayza (2000), and Rousseau and Wachtel (2000). Newer literature, however, argues that the positive association between credit and GDP growth disappears or even turns negative at high ratios of credit to GDP. See Chong et a. (2017) and the sources cited there.

${ }^{15}$ See Appendix II and Annex II.2 for details on the data.

${ }^{16}$ Barro (1991) motivates the use of public consumption as a control variable in growth regressions. Loayza and Ranciere (2006) find that financial deepening has a negative short-run effect on GDP growth and a positive long-run effect.
} 
capital proxied by the country's main monetary policy rate to maximize the sample size. ${ }^{17}$ In addition, as in the specification for GDP growth, we include the ratio of bank credit to the private sector to GDP, the growth rate of external demand, the volatility index (VIX), and the recession/recovery dummies.

$$
\begin{gathered}
\text { GFCF }_{i t}=\alpha_{i}+\alpha_{1} \text { GFCF }_{i t-1}+\alpha_{2} \text { Credit }_{i t}+\alpha_{3} G G B A L_{i t}+\alpha_{4} \text { CreditGDP }_{i t} \\
+\alpha_{5} \text { Interest }_{i t}+\alpha_{6} \text { Extdem }_{i t}+\alpha_{7} \text { VIX }_{t}+\varepsilon_{i t}
\end{gathered}
$$

Here $G F C F$ is the growth rate of private gross fixed capital formation, GGBAL is the ratio of the general government balance to GDP and Interest is the country's monetary policy rate.

\section{Results}

\section{Bank credit extended to the private sector has positively, but moderately influenced} economic activity in European countries. Table 3.2 shows that a 10 percentage points increase in the growth of bank credit to the private sector - not a trivial jump - would raise real GDP growth by $0.6-1$ percent depending on specification and sample. The main channel seems to be private investment. Table 3.3 shows that a 10 percentage points increase in bank credit growth raises private GFCF by some $2-2 \frac{1}{2}$ percent. Given the weight of private investment in GDP (generally ranging from 20-30 percent in European countries), the effect of bank credit on investment explains the bulk of its effect on GDP.

\section{The GFC-induced recession did not change the relationship between bank credit growth and GDP growth, while the subsequent recovery did turn creditless for many} countries that experienced a pre-GFC credit boom. Table 3.2 shows that the interaction terms capturing the effect of credit growth on GDP growth during the post-GFC recession is not statistically significant in any specification. However, the recovery period merits an indepth look given our finding in Section II of subdued credit dynamics persisting well into the recovery. The literature has called periods of positive GDP growth rates and negative credit growth rates "creditless recoveries" (Abiad, Dell'Ariccia, and Li, 2011; Abdoun et al., 2014). Such episodes have been documented in both advanced economies (AEs) and CESEE countries during the period of our analysis. ${ }^{18} \mathrm{We}$ did not find systematic conclusive evidence in favor of creditless recoveries when analyzing the full sample as well as the AE and CESEE country groups (columns (4)-(6) in Table 3.2). ${ }^{19}$ However, it is possible that the

\footnotetext{
${ }^{17}$ For the euro area and the UK, we use the so-called shadow policy interest rate as defined in Wu and Xia (2016), which incorporates the effects of unconventional monetary policies.

${ }^{18}$ For a sample of 59 advanced and emerging market countries, Abdoun et al. (2014) finds a negative correlation between credit growth and GDP/investment growth during creditless recoveries, which the authors consider consistent with balance sheet repair and/or substitution of alternative funding for bank credit.

${ }^{19}$ On the other hand, Table 3.3 does show some evidence of "creditless investment" for the subsample of AE countries in the recovery period (column (5)). The combined coefficient on credit growth for the recovery period (the sum of the main credit growth coefficient and that of the interaction term) is not statistically significant, with a value of -0.13 and a standard error of 0.20 ). This is consistent with the finding in Section II of investment overperforming historical patterns, while bank credit has underperformed.
} 
division between countries with normal and creditless recoveries is not along regional lines, but based on other indicators. One such possible indicator, consistent with the hypothesis of burdened balance sheets precluding credit growth, is the existence of a pre-crisis credit boom. The observed pre-GFC credit booms in many European countries may have left their firms and households with overstretched balance sheets, necessitating borrowing restraint even when demand strengthened. To investigate this hypothesis, the regressions in columns (7) and (8) in Table 3.2 interact the credit-growth-in-recovery variable with a "boom" dummy, taking the value of 1 if the country has experienced a pre-GFC credit boom based on the Mendoza and Terrones (2012) methodology. Indeed, for countries with pre-GFC credit booms the combined coefficient on credit growth during the post-GFC recovery is small and statistically insignificant (column 7). This result is confirmed in the sub-sample of AEs as well (column 8). ${ }^{20}$

\section{Similar results are obtained when we expand the definition of credit to the private non- financial sector by including non-bank sources, like bond issuance, supplier credit, and} lending by non-bank financial companies. Table 3.4 shows these results for a subsample based on available data. Again, a 10 percentage points increase in total credit growth is associated with a 0.7 percentage points rise in GDP growth, and this relationship remains steady in the post-GFC recession and recovery periods. ${ }^{21}$

\section{How confident can we be in the finding of positive but moderate association/influence between/of credit growth and/on GDP/investment growth? This depends mainly on the} extent to which we have managed to obtain unbiased and consistent coefficient estimates by reducing the endogeneity created by the likely two-way causality between GDP growth and credit growth, as well as other regressors. Although our system GMM estimator does reduce endogeneity considerably by design, our set of internal instruments only (lags of the regressors) may not be sufficiently strong for this purpose. As a robustness test on the amount of residual endogeneity left in the regressions, we do the following:

\section{- Introduce a new set of instruments that we can reasonably expect to be exogenous.} These instruments are based on the banks' answers to credit supply-related surveys of lending standards conducted by many European central banks. To make these instruments as exogenous to economic activity as possible, we look at the components of banks' answers and exclude those related to the economic situation. ${ }^{22}$

\footnotetext{
${ }^{20}$ The combined coefficient in column 7 is -0.05 with a standard error of -0.06 , and in column (8) it is 0.01 with a standard error of 0.07. Data limitations do not allow robust estimation of this specification for CESEE countries alone.

${ }^{21}$ In the spirit of Rajan and Zingales (1998), we also checked if manufacturing sectors that are less reliant on external (to the firm) financing performed better than other sectors during creditless recoveries in European countries, given the disruption in the supply of credit after the GFC. The results, however, did not support this hypothesis. Explanations may include: (i) the timing of the recovery of specific country-sectors may not match the timing of the overall country recovery; and (ii) the financing structure of different sectors is very country-specific and do not match the sector ordering in the index of external financing developed by Rajan and Zingales (1998) and updated by Kroszner et al (2007), which is based on the U.S.

${ }^{22}$ This approach follows the methodology in IMF (2013), Annex 2.2.
} 
- Run the GDP growth regression (column (1) in Table 3.2), adding three various combinations of lending-standard-based instruments to our initial set of internal instruments (Table 3.1). Since the new instruments are less influenced by economic activity, but correlated with credit growth (as they describe supply-side credit conditions), they should further reduce any residual endogeneity in the regression. If they do, and this effect is important, we would expect the coefficients in the new regressions to be quite different (and more reliable) than the ones in the baseline regression. If, on the other hand, residual endogeneity is not a big problem in the original regression (the baseline), the new regressions should result in basically unchanged coefficients relative to the baseline. So, a test on whether the coefficients in the new regressions are equal to those in the baseline one is tantamount to a test whether we can rely on the original estimates. ${ }^{23}$

- Wald tests indicate that the estimated values of the coefficients in the new regressions are indeed not statistically different from the baseline (Table 3.1). Therefore, the results from the original regressions (presented in Table 3.2), relying on internal instruments only but utilizing a larger sample, appear to describe adequately the relationship between credit growth and GDP growth.

\begin{tabular}{|c|c|c|c|c|}
\hline Coefficients: & $\begin{array}{c}\text { Baseline 1/ } \\
\text { (1) }\end{array}$ & $\begin{array}{r}+\mathrm{LS}-3 \quad 2 / \\
(2)\end{array}$ & $\begin{array}{r}+\mathrm{LS}-23 / \\
(3)\end{array}$ & $\begin{array}{c}+\mathrm{LS}-14 / \\
(4)\end{array}$ \\
\hline GDP growth (lagged) & 0.137 & 0.162 & 0.149 & 0.184 \\
\hline Credit growth & 0.133 & 0.091 & 0.116 & 0.125 \\
\hline Public consumption & -0.735 & -0.476 & -0.602 & -0.695 \\
\hline Credit/GDP & -0.104 & -0.086 & -0.090 & -0.094 \\
\hline External demand & 0.230 & 0.252 & 0.227 & 0.235 \\
\hline VIX & 0.003 & -0.001 & -0.001 & 0.003 \\
\hline Constant & 0.091 & 0.084 & 0.090 & 0.082 \\
\hline \multicolumn{5}{|c|}{ Wald tests for equality of the coefficients in regressions (2), (3), and (4) with those in (1) } \\
\hline Chi2 (6) & & 2.33 & 0.75 & 0.31 \\
\hline Prob $>$ Chi2 & & 0.887 & 0.993 & 0.999 \\
\hline \multicolumn{5}{|c|}{$1 /$ Internal instruments (lags) only. } \\
\hline \multicolumn{5}{|c|}{ 2/ With lending standards-based instruments for companies, households (HH)-mortgage, and HH-consumer credit. } \\
\hline \multicolumn{5}{|c|}{ 3/ With lending standards-based instruments for companies and the average of $\mathrm{HH}$-mortgage and $\mathrm{HH}$-consumer credit. } \\
\hline \multicolumn{5}{|c|}{ 4/ With the average of the lending standards-based instruments for companies, $\mathrm{HH}$-mortgage, and $\mathrm{HH}$-consumer credit. } \\
\hline \multicolumn{5}{|c|}{5 / Shows the probability of not rejecting the null hypothesis of coefficient equality. } \\
\hline
\end{tabular}

The approach taken to obtain sound econometric estimates in this and the following two sections deserves some further elaboration. In general, GDP and investment growth (as well as bank lending and profitability, discussed later) are highly endogenous variables in the economic system. Moreover, any panel estimation, especially dynamic panels like ours, has to handle heterogeneity across units as well as ensure independence of the regression

\footnotetext{
${ }^{23}$ The reader may wonder why we don't simply report only the set of results that includes the lending standards-based instruments, as the latter are clearly valid. This is costly, however, as the use of these instruments halves the sample and reduces the precision of the estimation (indeed, these reasons prevented performing the same procedure for the investment regression). Moreover, it limits the analysis to countries and years with existing surveys of lending standards, thus making it less representative of the overall European conditions.
} 
residuals, both in the time and cross-section dimensions. We address these issues in several ways. First, we use the system GMM estimator, which is in principle well suited to reduce endogeneity in a dynamic panel. Furthermore, as just discussed, we also experimented with additional instruments to obtain a degree of comfort that our estimates in this section are not affected by residual endogeneity in a material way. Second, overfitting of the endogenous variables with too many instruments can be an issue when using the GMM technique. As a mitigation, the estimation minimized the number of instruments, following Roodman (2009) so that the number of instruments is at most equal to the number of countries in each panel. Third, while our GMM estimator provides heteroscedasticity-consistent standard errors, to minimize the effect of country heterogeneity we also ran regressions using more homogeneous sub-samples that grouped countries with significant similarities (e.g. advanced and emerging Europe). Finally, to reduce the likelihood of cross-sectional correlation, a challenge that is present in all panel estimations, we have tried to control for common factors that affect most of the countries in our sample by including a measure of external demand (which controls for global/regional economic ups and downs), and the VIX (a measure of volatility possibly caused by global shocks) in the regression models.

\section{An alternative assessment of the relationship between GDP growth and credit growth}

Biggs et. al (2009) find that the rebound of domestic demand after a financial crisis is highly correlated with the rebound in the flow of credit. The authors argue that recoveries only appear creditless when a relationship is sought between the stock of credit and the flow of economic activity (i.e., GDP). To the extent that economic activity is financed by borrowing, GDP would be a function of the flow of credit, and correspondingly GDP growth would be positively related to the change in credit growth (rather than credit growth itself), especially during recovery periods after financial crises. In this context, we proceed to assess the relationship between GDP growth and the change in credit growth for our sample and subsamples of European countries.

The change in bank credit growth (called a credit impulse) significantly affects GDP growth during the post-GFC recovery in European countries but not during the preGFC expansion or the subsequent recession (Table 3.5). During the recovery, the credit impulse coefficient is significant and similar in magnitude to the coefficients of bank credit growth in Table 3.2. Interestingly, no relation is observed before the GFC (the coefficient of the credit impulse is not significant), a period of rapid credit expansion, or during recession periods. ${ }^{24}$ Although in line with the conjecture in Biggs et. al (2009) that the credit impulse is more important in recoveries, this finding casts doubts over the relevance of this model, as most analysts would agree that credit extension significantly affected economic activity before the GFC.

\footnotetext{
${ }^{24}$ Although the interaction term for credit growth in recession in CESEE countries is statistically significant (column (6) in Table 3.5), the combined credit growth coefficient (the sum of the main coefficient and that of the interaction term) is not, with a value of 0.05 and a standard error of 0.04 .
} 


\section{FinANCIAL AND MACROECONOMIC IndiCATORS INFLUENCING CREDIT Growth}

\section{Having documented the weak credit dynamics after the GFC and their effects on the macroeconomy, we now turn to an analysis of the interactions between credit and} financial indicators at the bank level. This section looks at possible financial indicator influences on credit growth, while Section V analyzes the effect of credit on bank profitability, an important financial soundness benchmark.

We analyze the relationship between credit growth and financial/macroeconomic indicators in a large cross-country bank-level panel dataset, following the approach in Everaert et al. (2015). In this approach, credit growth is regressed against bank fundamentals, macroeconomic variables, and recession and recovery dummies to examine whether the relationship varies over the economic cycle. Compared to Everaert et al. (2015), we expand the country coverage and extend the time frame (39 countries over 1999-2015). The regression analysis is first conducted using the entire sample. Given the substantial country heterogeneity, the sample is then split into two distinct and more homogeneous parts: $\mathrm{AE}$ and CESEE. To alleviate endogeneity issues, we use the system GMM estimator of Blundell and Bond (1998), which instruments the right-hand side variables.

The benchmark specification of the regression is as follows:

$$
c g_{i t}=\emptyset_{i}+\alpha B_{-} F U N D_{i, t}+\beta M A C R O_{j t}+\lambda \text { Recession }+\delta \text { Recovery }+v_{i t}
$$

where subscripts $i, j$, and $t$ denote bank, country, and year respectively. The dependent variable $c \boldsymbol{g}$ is the real annual growth rate of gross bank loans.

The following variables are included in the analysis. $B_{-} F U N D$ refers to a set of individual bank fundamentals. Deposit growth is the annual change of domestic deposits scaled by total assets and is expected to be positively correlated with credit growth. Banks with more funding should have a stronger lending growth. Capitalization, defined as total bank capital scaled by assets measures the solvency of the bank. This variable's sign is a priori ambiguous. It could be positive as better capitalized banks have a higher capacity to expand credit, or negative if banks are boosting their capital ratio by reducing risky assets. Bank liquidity, proxied by liquid assets as a ratio of total assets, is expected to have a positive sign, as more liquidity would tend to facilitate new lending. Loan quality, proxied by the nonperforming loan (NPL) ratio, as a percent of gross loans is anticipated to be negatively correlated with credit growth. As loan quality deteriorates, banks have less capacity and willingness to extend new credit. Finally, the return on assets may be positively correlated with credit growth, as higher retained earnings provide banks with the capacity to increase their lending activities. $M A C R O$ includes the following macroeconomic variables: (i) GDP growth with an expected positive sign; (ii) Average inflation, with an expected negative sign as lack of price stability deters financial transactions and inflation erodes bank capital. Recession and Recovery are dummy variables taking a value of 1 during post-GFC recessions/recoveries and 0 otherwise. 
Overall, the econometric results point to loan quality, customer deposits, bank equity price index, and bank capital, as well as the macroeconomic environment as key factors influencing bank credit dynamics (Figure 6 and Table 4.1):

- Poor loan quality is associated with a decline in credit extension: the higher the NPL ratio, the higher the expectation of even more trouble in bank portfolios and the less the appetite for lending. The average NPL ratio of the banks in our sample stood at around 8 percent in the post-GFC recovery compared to less than 5 percent during the gradual acceleration and boom period (1999-2008), hampering bank lending during the post-GFC recovery. During recoveries, the NPL's negative impact is tempered by the renewed buoyancy of economic activity.

- As expected, customer deposits are positively associated with credit growth, suggesting that strong and stable savings mobilization facilitates credit expansion. While deposits grew robustly at an average annual rate over 20 percent during the 19992008 period, this has tempered down in the postGFC recovery to just about 9 percent, contributing to subdued bank lending as well.

- The bank equity price index is also significant with a positive sign as higher bank equity prices reflect healthy bank balance sheets that allow credit expansion. This effect is reversed in recessions, though, as bank equity prices drop quickly and strongly, while lending's reaction to the worsened economic environment is slower and more muted.

- The bank capital variable is significant with a negative sign in recessions only, an indication that the need to raise capital in a recession may hinder lending, to the extent the capital hike is accomplished through deleveraging; the effect is quantitatively small, however.

- Real GDP growth is significant with a positive sign, highlighting the importance of aggregate demand factors. ${ }^{25}$
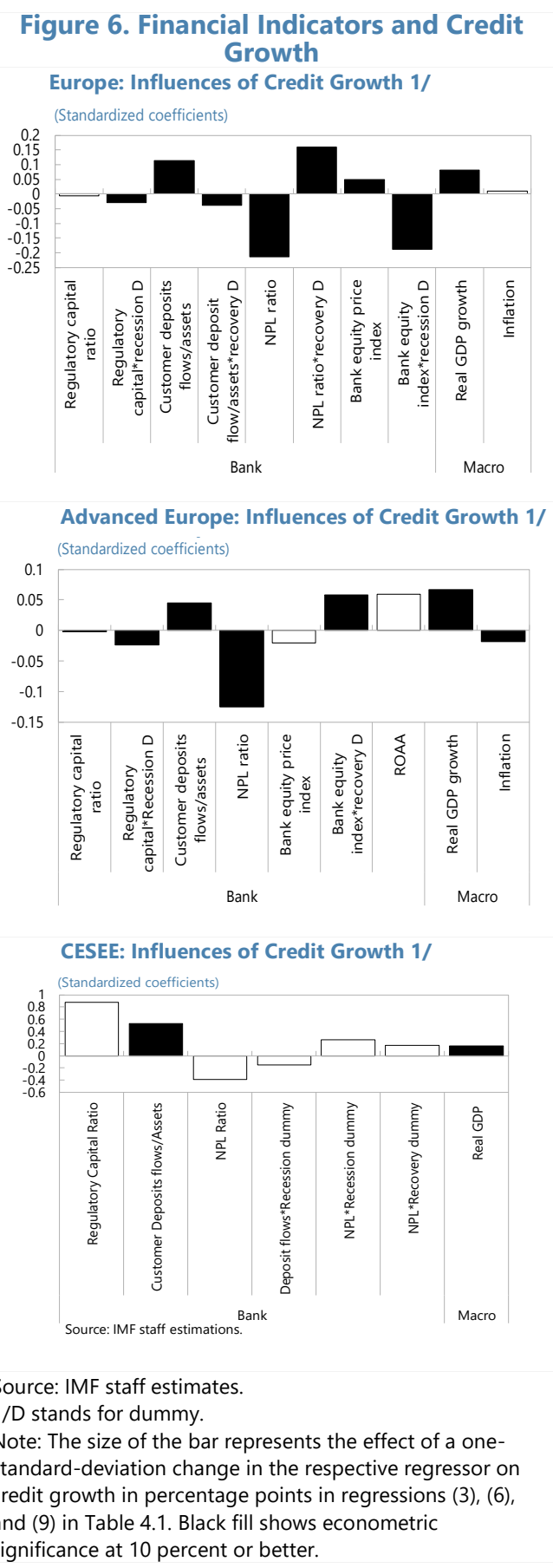

\footnotetext{
${ }^{25}$ Our analysis in this section shows that both demand and supply factors are responsible for the sluggish pots-GFC credit growth. A more specific answer on which factor is primarily responsible requires more disaggregated data and is usually
} 
The estimation results for the advanced European countries broadly confirm the key driving factors highlighted above. Inflation is significant here (but just at a 10 percent significance level) with a negative sign, further confirming the importance of the macroeconomic environment.

The results for the CESEE countries are less robust, with only customer deposits and real GDP growth passing statistical significance tests. This may reflect the fact that many banks in CESEE countries are subsidiaries of foreign banks from Western Europe, so the implicit support of the parent bank may have made domestic bank indicators (on capital, NPLs, etc.) less important for credit extension.

\section{Credit Growth and Bank Profitability}

Credit growth and bank profitability are strongly related, since extending credit is the primary function of most banks. Credit has both direct and indirect effects on profitability. First, the stock of loans directly and positively affects interest income, commissions and fees, and loan loss provisions. Second, credit growth, together with other macroeconomic and bank-specific conditions and policies, influence the interest charged, the deposit rate offered by banks, and their fee structure. Third, credit growth, together with prudential regulation and individual bank credit policies, affects over time banks' provisions and loan loss rate. As credit growth contracted after the GFC (Figure 7), it is important to understand how this influenced bank profitability, a key financial soundness indicator.

We examine the effect of credit growth on several measures of bank income and profitability. The following income components are likely to be affected by credit growth: (i) gross interest income; (ii) net interest income; and (iii) commissions and fees income. We also add four measures of profitabilitydeducting expenses from income-with varying strength of the relationship with credit growth: (iv) pre-impairment income; (v) operating income; (vi) pretax income; and (vii) net income. All seven measures are scaled by total assets.

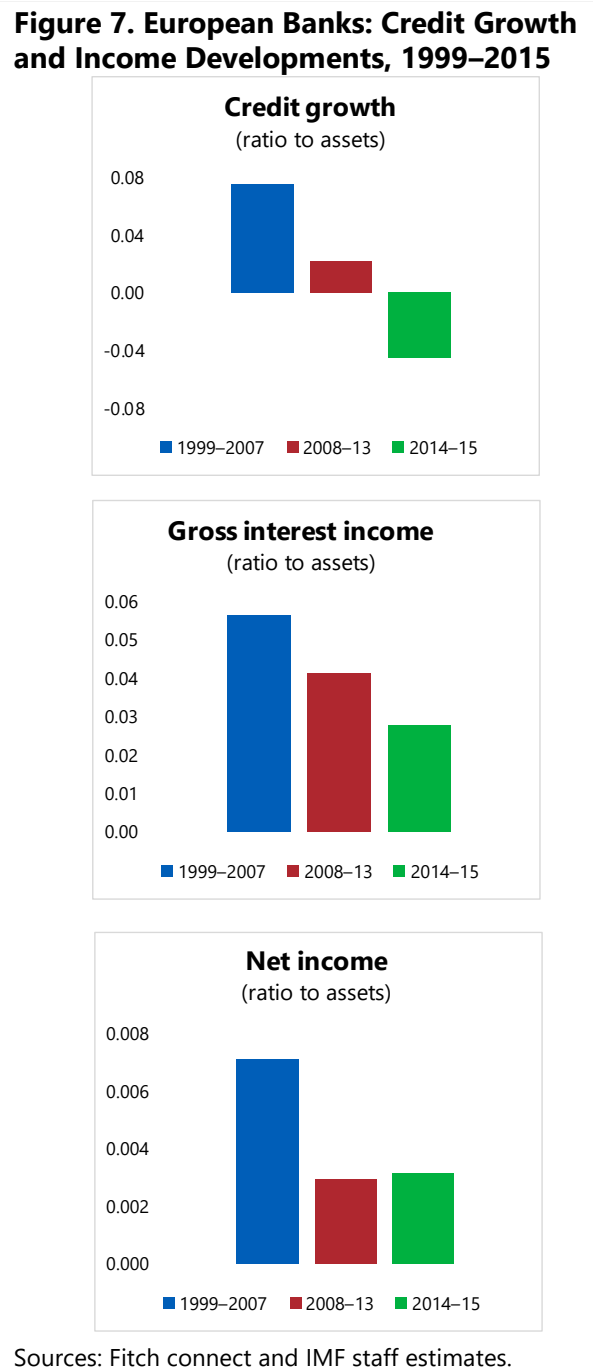

Sources: Fitch connect and IMF staff estimates.

done for individual countries rather than in a panel. Del Giovane, Eramo, and Nobili (2011) for instance find — using micro data - that both demand and supply factors matters in the case of Italy. Dumičić and Ljubaj (2017) find the same for Croatia and shows that determinants for demand and supply are different for households and non-financial companies. 
Profitability is also affected by various types of risks. We include widely used control variables that capture credit risk, funding risk, and liquidity risk. To investigate how the impact of credit varies during the pre-crisis, recession, and recovery periods, we use recession and recovery dummies consistent with the rest of the paper. We estimate the following dynamic panel regression:

$$
\begin{aligned}
P_{\mathrm{jt}}=\mathrm{c}_{0} & +\mathrm{c}_{1} L O A N_{\mathrm{jt}}+\mathrm{c}_{2} C A P I T A L_{\mathrm{jt}}+\mathrm{c}_{3} C R E D I T_{\mathrm{jt}}+\mathrm{c}_{4} F U N D I N G_{\mathrm{jt}}+\mathrm{c}_{5} L I Q U I D I T Y_{\mathrm{jt}}+\mathrm{c}_{6} S I Z E_{\mathrm{jt}} \\
& +\mathrm{c}_{7} T Y P E_{\mathrm{jt}}+\mathrm{c}_{8} C R I S I S_{\mathrm{jt}}+\mathrm{c}_{9} R E C O V E R Y_{\mathrm{jt}}+\mathrm{f}_{\mathrm{jt}}
\end{aligned}
$$

where $j$ is the index for individual banks; $t$ is the time index for annual data, 1999-2015; $P$ is one of the seven measures of bank income/profitability defined above; $L O A N$ is credit growth (the change in gross loans over assets); CAPITAL is equity over assets; CREDIT is a measure of credit risk (the gross NPL ratio); FUNDING is a measure of funding risk (the share of deposits in total funding); LIQUIDITY is liquid assets over total assets; SIZE is the $\log$ of total assets; TYPE is a dummy variable for bank specialization; and CRISIS/RECOVERY are dummy variables for the recession and recovery periods (the pre-crisis period is the base). ${ }^{26} \mathrm{We}$ interact CRISIS and RECOVERY with the other variables to see whether their influence on profits varies between the three periods of the sample. As elsewhere in the paper, the estimation is carried out using a system GMM estimator.

Credit growth is significantly and positively associated with all measures of income and profitability. (Figure 8, top left panel and Table 5.1). As expected, the coefficient on credit growth is the largest for the gross interest income, as credit has the most direct effect on income through lending volumes. In the pre-crisis and post-GFC recovery periods, an increase in credit growth equivalent to one percentage point of assets implies a rise in gross interest income equal to 0.08 percentage points of assets. Furthermore, the broader the definition of profitability, the smaller the impact of credit growth, since these broader definitions also reflect non-lending activities and expenses of banks.

\section{Credit growth is significant throughout the whole period, but its influence falls sharply} in recessions. Credit extension significantly and positively affects most measures of bank income and profits in the pre-crisis and post-crisis recovery periods (Table 5.1). Moreover, it appears that the influence of credit on bank income/profits on has remained practically the same in the pre-crisis period and the recovery, as the interactive term for credit growth in recovery periods is not significant in most specifications. However, this relationship has apparently broken during the post-GFC recessions in some specifications (Table 5.1). ${ }^{27}$ This

\footnotetext{
${ }^{26}$ Although monetary policy is indeed important for bank profitability (Borio et al, 2015), a measure of interest rates is not included to avoid over-specification, since the quantity of credit is already present in the regression. Macroeconomic variables such as GDP growth and the short-term interest rate are assumed to affect bank profits through the quantity of credit. The inclusion of the yield curve slope and alternative definitions of some variables did not alter the main findings.

${ }^{27}$ While the interaction term of credit and recession in columns (2), (7), and (8) in Table 5.1 is negative and statistically significant, the combined coefficient of credit is not significant for column (2) (gross interest income), suggesting a break in the relationship between credit and bank interest income in the recession periods. The combined coefficient is negative and
} 
effect stems largely from the coexistence of sharply falling lending during the GFC and more resilient bank profits due to cost adjustments, profits from short trading, etc.

\section{Credit growth nevertheless remains the most significant explanatory variable for} profits. Credit growth, and - in some specifications - the first lag of profits and the NPL ratio have the greatest statistical significance. For gross interest income, besides the first lag of profits, which controls for the autocorrelation structure but does not contribute to the economic explanatory power, the t-statistic for credit growth by far exceeds the other $\mathrm{t}$ statistics (Figure 8, bottom panel).

Credit growth explains about half of the variation in banks' interest income. To assess the economic significance of the explanatory variables, we re-ran the regressions using the standardized variables (demeaned and scaled by their standard deviation). Figure 8 (top right panel) demonstrates that credit growth explains 50/40 percent of the variation in the gross and net interest income equations, respectively. The complete results are shown in Table 5.2.

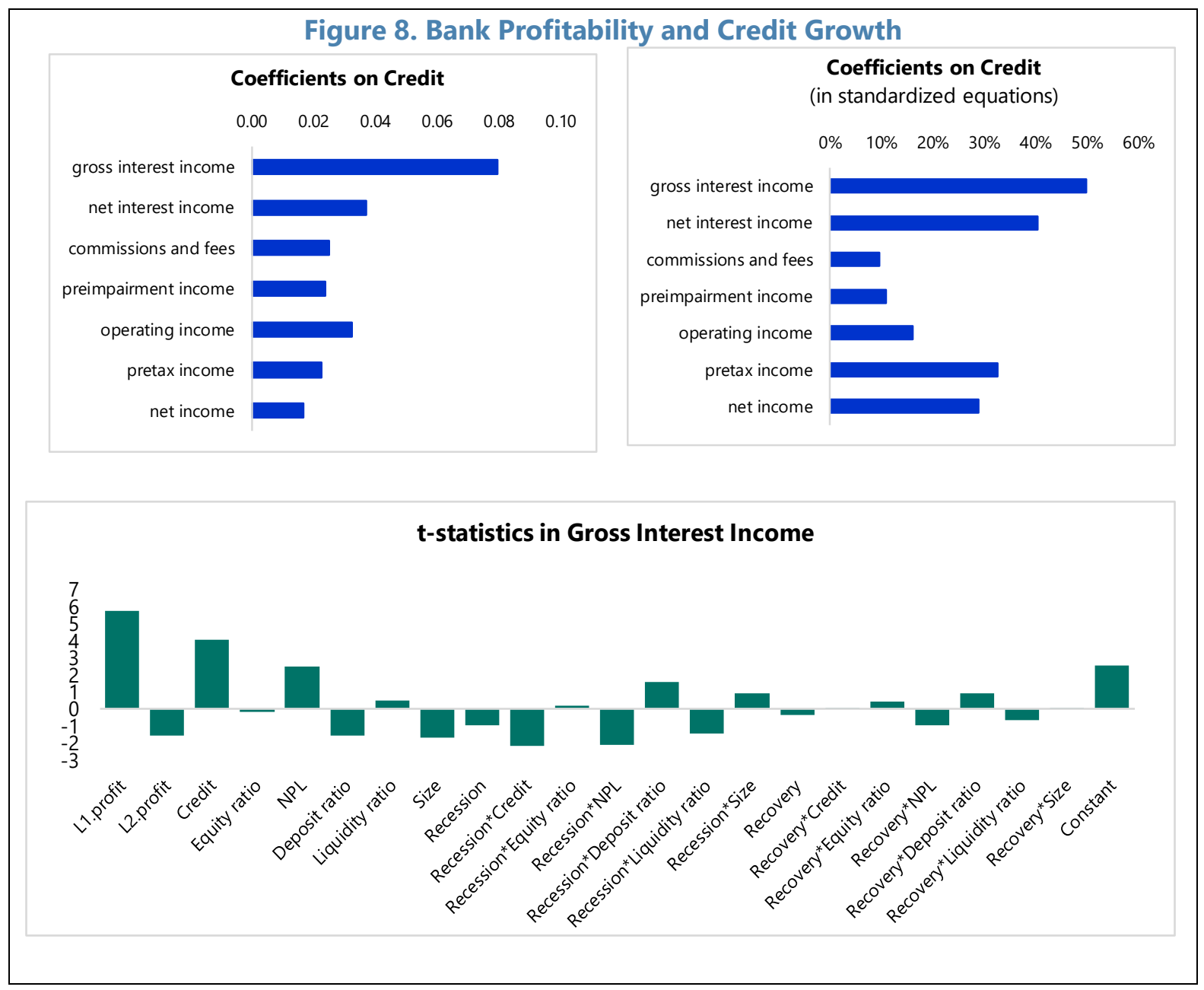

significant at a 5 percent level in columns (7) and (8) (pre-tax income and overall net income), but we regard this as a statistical fluke as explained in the text. 


\section{SUMMARY OF MAIN FindingS}

This section summarizes the main findings of our analysis of the role of aggregate bank credit to the private sector in European recessions and recoveries since the GFC. The paper benefits from an expanded sample and more recent data that help to better address the inevitable econometric challenges and shed more light on the effects of credit on the economy during the post-GFC recovery. Further research might also incorporate the effects of the different policy approaches among European countries. For instance, the approach to handling NPLs and foreign currency denominated lending varied among the countries.

Countries that did not suffer a financial crisis during and after the GFC had output and credit recoveries that were much worse than historical experience would suggest. This holds even after controlling for unusually weak external demand conditions, which reflect the global reach of the crisis. Output in these countries may have been held back by adverse financial spillovers from those economies that did suffer a financial crisis, something that the regressions did not control for. While countries without a financial crisis and with a flexible exchange rate did better immediately after the crisis, countries with a de facto fixed exchange rate caught up later. This likely reflects the slower adjustment of variables such as real wages and prices in the absence of exchange rate flexibility.

Countries that did suffer a financial crisis during and after the GFC also had a much worse recovery than historical patterns would suggest. However, after controlling for unusually weak external demand conditions their recoveries are no longer significantly weaker in a statistical sense. In this case, floaters that had a financial crisis seem to have done better, but the sample is so small that other country-specific factors may have also been at play. Interestingly, credit dynamics for European countries that experienced a banking crisis during and after the GFC, bad as they were, fall broadly in line with the experience after other financial crises during the 1972-2006 period.

If the GFC and the euro area sovereign debt crisis are treated as one recessionary episode, the subsequent recovery is in line with-or better than-historical patterns. The latter crisis was related to the former and both can be viewed as having been triggered by a single shock. The double whammy nature of the shock may also explain why the CESEE economies, which have less strong economic relations with the euro area crisis economies, have generally recovered faster and are closer to the paths suggested by historical experience than the advanced euro area economies.

Investment in all country groups overperforms historical patterns, once we control for the euro area sovereign debt crisis, while credit underperforms. This indicates that firms are increasingly relying on non-bank financing for their investment needs. The EU structural and cohesion funds may have also helped sustain investment in some EU members. 
Bank credit dynamics have positively but moderately influenced economic activity indicators. A 10 percent increase in domestic bank credit to the private sector would raise real GDP by about $0.6-1$ percent, working mainly through the investment channel. The relationships between credit growth, GDP growth, and investment appear to have stayed robust through the post-GFC recession and recovery overall. However, we found some evidence of post-GFC creditless recoveries in economies that experienced a credit boom prior to the GFC. We also investigated whether our estimates are sufficiently reliable, in the sense of not being much affected by the inherent endogeneity in our regression specification. We found this indeed to be the case, as adding further instruments based on lending surveys of bank officers did not change the estimates significantly.

The analysis of individual bank and macro factors influencing credit growth is broadly in line with our priors. Large customer deposits and high bank equity prices are associated with stronger credit extension, while high NPL ratios with weaker credit growth. ${ }^{28}$ These relationships did not change significantly during and after the GFC. Had data permitted, it would have also been interesting to gauge whether the Texas ratio would have been a better proxy for the effect of NPLs on banks' ability to lend..$^{29}$ Moreover, stronger real growth is positively correlated with real credit growth, implying an important role for demand factors.

As expected, exceptionally weak credit dynamics were also associated with weaker bank profitability. Credit growth is important for all income components and measures of profitability, explaining about half of the variation in bank interest income and a smaller share of other income components. However, the influence of credit falls sharply in some cases during post-GFC recessions, an effect likely driven by the coexistence of sharply falling lending and more resilient bank profits buttressed by other financial activities.

Stimulating credit growth is not a substitute for needed reforms. The recovery from the balance sheet recession triggered by the GFS took time, keeping economic activity and bank credit suppressed as households and firms rebuild their financial buffers. While bank credit is flowing again in 2017, its support for the ongoing recovery appears to be moderate, as economies have seemingly learned to live with less bank borrowing. Attempts to stimulate lending at any cost are therefore likely to have modest payoff but large adverse side effects, as the GFC showed. Moreover, should credit rise ahead of economic fundamentals, financial and macroprudential policies should curb these developments to avoid credit crash-led recessions later. Strong credit growth is thus no substitute for a concerted package of reforms addressing bottlenecks to economic growth, while preserving macroeconomic stability.

\footnotetext{
${ }^{28}$ Our results thus support recent IMF analysis and advice — proactive bank disposal of impaired loans, combined with improved legal framework and tax system that incentivizes prompt handling of problem loans, are vital to reinvigorate sustainable credit growth (IMF, 2015A).

${ }^{29}$ The Texas ratio can be defined as the value of the lender's non-performing assets divided by the sum of its tangible common equity capital and loan loss reserves. If a viable bank has a large portfolio of un-provisioned loans and a modest capital buffer over the required regulatory capital, it may be more risk averse.
} 


\begin{tabular}{|c|c|c|c|c|c|c|c|c|}
\hline \multicolumn{9}{|c|}{ Table 3.2 Credit Growth and GDP Growth } \\
\hline \multicolumn{9}{|c|}{$\begin{array}{l}\text { Dynamic panel data; two-step GMM estimator } \\
\text { Sample of } 39 \text { European countries, estimation period: 1999-2015 }\end{array}$} \\
\hline & $\begin{array}{c}\text { (1) } \\
\text { Full sample }\end{array}$ & $\begin{array}{l}(2) \\
\mathrm{AE}\end{array}$ & $\begin{array}{c}(3) \\
\text { CESEE }\end{array}$ & $\begin{array}{l}\text { (4) } \\
\text { Full sample }\end{array}$ & $\begin{array}{l}(5) \\
\mathrm{AE}\end{array}$ & $\begin{array}{c}(6) \\
\text { CESEE }\end{array}$ & $\begin{array}{c}\text { (7) } \\
\text { Full sample }\end{array}$ & $\begin{array}{l}(8) \\
\mathrm{AE}\end{array}$ \\
\hline GDP growth rate (t-1) & $\begin{array}{l}0.199 * * \\
(0.088)\end{array}$ & $\begin{array}{l}0.224^{\star *} \\
(0.076)\end{array}$ & $\begin{array}{l}0.150^{* *} \\
(0.056)\end{array}$ & $\begin{array}{l}0.200^{* *} \\
(0.095)\end{array}$ & $\begin{array}{c}0.199^{* \star *} \\
(0.047)\end{array}$ & $\begin{array}{c}0.079 \\
(0.070)\end{array}$ & $\begin{array}{l}0.214^{\star \star \star} \\
(0.048)\end{array}$ & $\begin{array}{c}0.082 \\
(0.082)\end{array}$ \\
\hline GDP growth rate (t-2) & & $\begin{array}{l}-0.183^{\star *} \\
(0.067)\end{array}$ & & & & & & \\
\hline Private sector credit growth & $\begin{array}{l}0.094^{\star *} \\
(0.045)\end{array}$ & $\begin{array}{l}0.074^{\star \star} \\
(0.026)\end{array}$ & $\begin{array}{l}0.058^{\star \star \star} \\
(0.010)\end{array}$ & $\begin{array}{l}0.086^{* \star} \\
(0.029)\end{array}$ & $\begin{array}{l}0.102^{\star *} \\
(0.035)\end{array}$ & $\begin{array}{l}0.069^{\star *} \\
(0.021)\end{array}$ & $\begin{array}{l}0.091^{\star \star *} \\
(0.022)\end{array}$ & $\begin{array}{l}0.180^{\star \star \star} \\
(0.050)\end{array}$ \\
\hline Private sector credit growth * & & & & 0.076 & -0.048 & 0.028 & -0.011 & -0.064 \\
\hline Dummy recession ${ }^{1 /}$ & & & & $(0.081)$ & $(0.095)$ & $(0.098)$ & $(0.053)$ & $(0.067)$ \\
\hline Private sector credit growth * & & & & 0.011 & -0.171 & -0.047 & & \\
\hline Dummy recovery ${ }^{2 /}$ & & & & $(0.062)$ & $(0.118)$ & $(0.076)$ & & \\
\hline $\begin{array}{l}\text { Private sector credit growth * } \\
\text { Dummy recovery * pre-GFC credit boom }\end{array}$ & & & & & & & $\begin{array}{l}-0.137^{\star *} \\
(0.061)\end{array}$ & $\begin{array}{l}-0.169^{\star \star} \\
(0.081)\end{array}$ \\
\hline $\begin{array}{l}\text { Private sector credit growth * } \\
\text { Dummy recovery * pre-GFC no credit boom }\end{array}$ & & & & & & & $\begin{array}{l}0.040 \\
(0.080)\end{array}$ & $\begin{array}{l}-0.069 \\
(0.060)\end{array}$ \\
\hline Public consumption growth rate & $\begin{array}{l}-0.741 \\
(0.496)\end{array}$ & $\begin{array}{l}0.268^{\star *} \\
(0.110)\end{array}$ & $\begin{array}{l}0.031 \\
(0.065)\end{array}$ & $\begin{array}{l}-0.513^{\star *} \\
(0.239)\end{array}$ & $\begin{array}{l}0.125^{*} \\
(0.066)\end{array}$ & $\begin{array}{l}-0.094 \\
(0.182)\end{array}$ & $\begin{array}{l}-0.212 \\
(0.131)\end{array}$ & $\begin{array}{l}0.069 \\
(0.073)\end{array}$ \\
\hline Private sector credit-to-GDP ratio & $\begin{array}{l}-0.057^{\star *} \\
(0.025)\end{array}$ & $\begin{array}{l}-0.028^{* *} \\
(0.013)\end{array}$ & $\begin{array}{l}-0.035^{\star * \star} \\
(0.010)\end{array}$ & $\begin{array}{l}-0.031^{* *} \\
(0.010)\end{array}$ & $\begin{array}{l}-0.009^{* *} \\
(0.004)\end{array}$ & $\begin{array}{l}-0.035^{\star \star} \\
(0.012)\end{array}$ & $\begin{array}{l}-0.030^{\star *} \\
(0.014)\end{array}$ & $\begin{array}{l}-0.026^{* *} \\
(0.009)\end{array}$ \\
\hline External demand ${ }^{3 /}$ & $\begin{array}{l}0.284^{\star \star \star} \\
(0.062)\end{array}$ & $\begin{array}{l}0.115^{\text {** }} \\
(0.059)\end{array}$ & $\begin{array}{l}0.261^{\star \star \star} \\
(0.044)\end{array}$ & $\begin{array}{l}0.231^{\text {** }} \\
(0.097)\end{array}$ & $\begin{array}{l}0.171^{\text {** }} \\
(0.059)\end{array}$ & $\begin{array}{l}0.123^{* *} \\
(0.062)\end{array}$ & $\begin{array}{l}0.180^{* \star *} \\
(0.031)\end{array}$ & $\begin{array}{l}0.126^{\star *} \\
(0.050)\end{array}$ \\
\hline $\log (\mathrm{VIX})$ & $\begin{array}{l}-0.023^{\star \star \star} \\
(0.006)\end{array}$ & $\begin{array}{l}-0.020^{\star \star *} \\
(0.004)\end{array}$ & $\begin{array}{l}-0.026^{\star \star \star} \\
(0.005)\end{array}$ & $\begin{array}{l}-0.009^{\star *} \\
(0.004)\end{array}$ & $\begin{array}{l}-0.012^{\star *} \\
(0.005)\end{array}$ & $\begin{array}{l}-0.014 \\
(0.010)\end{array}$ & $\begin{array}{l}-0.010^{\star *} \\
(0.004)\end{array}$ & $\begin{array}{l}-0.019^{\star \star \star} \\
(0.005)\end{array}$ \\
\hline Constant & $\begin{array}{l}0.122^{\star *} \\
(0.039)\end{array}$ & $\begin{array}{l}0.091^{\star \star *} \\
(0.025)\end{array}$ & $\begin{array}{l}0.101^{\star \star *} \\
(0.017)\end{array}$ & $\begin{array}{l}0.064^{\star \star *} \\
(0.019)\end{array}$ & $\begin{array}{l}0.044^{\star *} \\
(0.019)\end{array}$ & $\begin{array}{l}0.081^{* *} \\
(0.033)\end{array}$ & $\begin{array}{l}0.063^{\star \star \star} \\
(0.018)\end{array}$ & $\begin{array}{l}0.083^{\star \star \star} \\
(0.024)\end{array}$ \\
\hline Dummy recession & & & & $\begin{array}{l}-0.026^{\star *} \\
(0.012)\end{array}$ & $\begin{array}{l}-0.016^{\star \star} \\
(0.006)\end{array}$ & $\begin{array}{l}-0.042^{\star \star \star} \\
(0.008)\end{array}$ & $\begin{array}{l}-0.026^{\star \star \star} \\
(0.006)\end{array}$ & $\begin{array}{l}-0.014^{\star *} \\
(0.004)\end{array}$ \\
\hline Dummy recovery & & & & $\begin{array}{l}0.005 \\
(0.005)\end{array}$ & $\begin{array}{l}0.010^{\star *} \\
(0.004)\end{array}$ & $\begin{array}{l}-0.0027 \\
(0.006)\end{array}$ & $\begin{array}{l}0.009^{* *} \\
(0.003)\end{array}$ & \\
\hline Recovery after credit booms & & & & & & & $\begin{array}{l}0.009^{* *} \\
(0.003)\end{array}$ & $\begin{array}{l}0.016^{\star *} \\
(0.006)\end{array}$ \\
\hline Recovery without credit booms & & & & & & & $\begin{array}{l}0.002 \\
(0.005) \\
\end{array}$ & $\begin{array}{l}0.013^{\star *} \\
(0.004)\end{array}$ \\
\hline No. Obs. & 618 & 349 & 269 & 618 & 349 & 269 & 616 & 349 \\
\hline No. instruments & 14 & 19 & 14 & 19 & 21 & 18 & 22 & 21 \\
\hline No. countries & 39 & 21 & 18 & 39 & 21 & 18 & 39 & 21 \\
\hline Autocorrelation test, $\mathrm{p}$-value & 0.451 & 0.462 & 0.566 & 0.463 & 0.183 & 0.346 & 0.628 & 0.401 \\
\hline Hansen test, $\mathrm{p}$-value & 0.218 & 0.233 & 0.543 & 0.228 & 0.153 & 0.497 & 0.258 & 0.469 \\
\hline Standard errors in parentheses. ${ }^{* \star \star} p<0.01$ & ${ }^{* *} p<0.05, * p$ & $<0.1$ & & & & & & \\
\hline Note: Data limitations do not allow running & regression (7) & for CESEE & countries. & & & & & \\
\hline The second lag of GDP growth rate is includ & ed in regressi & on (2) to re & move autoc & rrelation. & & & & \\
\hline 1 / Dummy takes the value of 1 during the re & cession perio & & & & & & & \\
\hline 2/ Dummy takes the value of 1 during the $p c$ & st-GFC recov & ery period. & & & & & & \\
\hline $3 /$ Volume of trading partners imports weig & ted by expor & ts' shares. & & & & & & \\
\hline
\end{tabular}

\section{CInternational Monetary Fund. Not for Redistribution}


Table 3.3 Credit Growth and Private Investment Growth

Dynamic panel data; two-step GMM estimator

Sample of 39 European countries, estimation period: 1999-2015

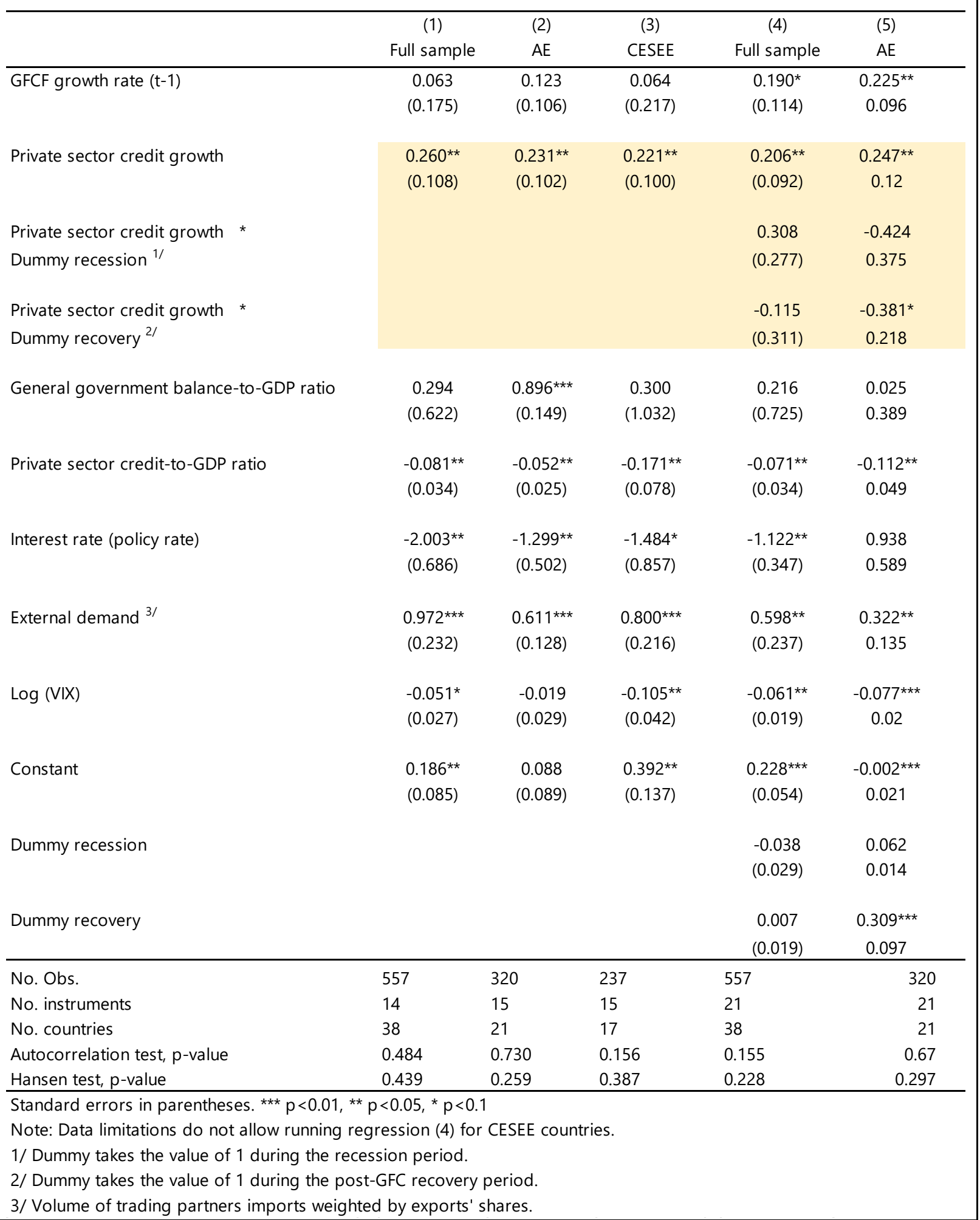




\begin{tabular}{|c|c|c|}
\hline \multicolumn{3}{|c|}{$\begin{array}{l}\text { Table 3.4 Credit Growth (total credit) and GDP Growth } \\
\text { Dynamic panel data; two-step GMM estimator } \\
\text { Sample of } 22 \text { European countries, estimation period: 1999-2015 }\end{array}$} \\
\hline & $\begin{array}{c}\text { (1) } \\
\text { Full sample }\end{array}$ & $\begin{array}{c}\text { (2) } \\
\text { Full sample }\end{array}$ \\
\hline GDP growth rate (t-1) & $\begin{array}{l}0.195^{\star * \star} \\
(0.057)\end{array}$ & $\begin{array}{l}0.178^{\star *} \\
(0.077)\end{array}$ \\
\hline Private sector total credit growth & $\begin{array}{l}0.067^{\star \star} \\
(0.022)\end{array}$ & $\begin{array}{c}0.067^{\star \star *} \\
(0.020)\end{array}$ \\
\hline Private sector total credit growth * & & -0.0169 \\
\hline Dummy recession ${ }^{1 /}$ & & $(0.067)$ \\
\hline Private sector total credit growth * & & 0.163 \\
\hline Dummy recovery ${ }^{2 /}$ & & $(0.115)$ \\
\hline Public consumption growth rate & $\begin{array}{l}0.338^{\star *} \\
(0.109)\end{array}$ & $\begin{array}{c}0.084 \\
(0.076)\end{array}$ \\
\hline Private sector credit-to-GDP ratio & $\begin{array}{l}-0.001 \\
(0.006)\end{array}$ & $\begin{array}{l}-0.021^{\star *} \\
(0.007)\end{array}$ \\
\hline External demand ${ }^{3 /}$ & $\begin{array}{l}0.280^{\star \star \star} \\
(0.045)\end{array}$ & $\begin{array}{c}0.201^{\star \star \star} \\
(0.033)\end{array}$ \\
\hline $\log (\mathrm{VIX})$ & $\begin{array}{c}-0.017^{\star \star \star} \\
(0.003)\end{array}$ & $\begin{array}{c}-0.014^{\star *} \\
(0.004)\end{array}$ \\
\hline Dummy recession & & $\begin{array}{l}-0.011^{*} \\
(0.006)\end{array}$ \\
\hline Dummy recovery & & $\begin{array}{c}0.011 \\
(0.004)\end{array}$ \\
\hline Constant & $\begin{array}{l}0.042^{\star *} \\
(0.016)\end{array}$ & $\begin{array}{l}0.073^{* *} \\
(0.023)\end{array}$ \\
\hline No. Obs. & 371 & 371 \\
\hline No. instruments & 19 & 21 \\
\hline No. countries & 22 & 22 \\
\hline Autocorrelation test, $p$-value & 0.632 & 0.807 \\
\hline Hansen test, $\mathrm{p}$-value & 0.226 & 0.328 \\
\hline $\begin{array}{l}\text { Standard errors in parentheses. }{ }^{* \star} p \\
\text { Note: Data limitations do not allow ru } \\
\text { 1/ Dummy takes the value of } 1 \text { during } \\
\text { 2/ Dummy takes the value of } 1 \text { during } \\
3 \text { / Volume of trading partners import }\end{array}$ & $\begin{array}{l}0.1 \\
\text { and }(2) \text { for } \\
\text { ry period. } \\
\text { s' shares. }\end{array}$ & and CESEE countries. \\
\hline
\end{tabular}

\section{CInternational Monetary Fund. Not for Redistribution}




\begin{tabular}{|c|c|c|c|c|c|c|}
\hline \multicolumn{7}{|c|}{$\begin{array}{l}\text { Dynamic panel data; two-step GMM estimator } \\
\text { Sample of } 39 \text { European countries, estimation period: 1999-2015 }\end{array}$} \\
\hline & $(1)$ & (2) & (3) & (4) & (5) & (6) \\
\hline & Full sample & $\mathrm{AE}$ & CESEE & Full sample & $\mathrm{AE}$ & CESEE \\
\hline GDP growth rate (t-1) & $\begin{array}{l}0.292^{\star \star \star} \\
(0.048)\end{array}$ & $\begin{array}{l}0.124 \\
(0.086)\end{array}$ & $\begin{array}{l}0.340^{* * *} \\
(0.062)\end{array}$ & $\begin{array}{l}0.269 * * \star \\
(0.057)\end{array}$ & $\begin{array}{l}0.189 * \star \star \\
(0.045)\end{array}$ & $\begin{array}{l}0.368^{\star \star \star} \\
(0.072)\end{array}$ \\
\hline GDP growth rate (t-2) & & $\begin{array}{l}-0.211^{\star *} \\
(0.074)\end{array}$ & & & $\begin{array}{l}-0.090 \\
(0.075)\end{array}$ & \\
\hline Change in private sector credit growth & $\begin{array}{l}0.020^{*} \\
(0.012)\end{array}$ & $\begin{array}{l}0.045^{\star} \\
(0.025)\end{array}$ & $\begin{array}{l}0.027^{*} \\
(0.016)\end{array}$ & $\begin{array}{l}-0.008 \\
(0.018)\end{array}$ & $\begin{array}{l}-0.033 \\
(0.031)\end{array}$ & $\begin{array}{l}-0.072 \\
(0.056)\end{array}$ \\
\hline Change in private sector credit growth * & & & & -0.009 & 0.006 & $0.120^{\star \star}$ \\
\hline Dummy recession ${ }^{1 /}$ & & & & $(0.035)$ & $(0.040)$ & $(0.050)$ \\
\hline Change in private sector credit growth * & & & & $0.114^{\star \star \star}$ & $0.097^{\star \star}$ & $0.166^{\star \star}$ \\
\hline Dummy recovery ${ }^{2 /}$ & & & & $(0.027)$ & $(0.040)$ & $(0.078)$ \\
\hline Public consumption growth rate & $\begin{array}{l}0.150 \\
(0.104)\end{array}$ & $\begin{array}{l}0.782^{\star \star \star} \\
(0.177)\end{array}$ & $\begin{array}{l}0.056 \\
(0.116)\end{array}$ & $\begin{array}{l}-0.248 \\
(0.160)\end{array}$ & $\begin{array}{l}0.459^{\star \star \star} \\
(0.118)\end{array}$ & $\begin{array}{l}-0.121 \\
(0.272)\end{array}$ \\
\hline Private sector credit-to-GDP ratio & $\begin{array}{l}-0.032^{\star \star} \\
(0.011)\end{array}$ & $\begin{array}{l}-0.011 \\
(0.011)\end{array}$ & $\begin{array}{l}-0.017 \\
(0.017)\end{array}$ & $\begin{array}{l}-0.020^{* *} \\
(0.007)\end{array}$ & $\begin{array}{l}-0.017 \\
(0.014)\end{array}$ & $\begin{array}{l}-0.009 \\
(0.025)\end{array}$ \\
\hline External demand ${ }^{3 /}$ & $\begin{array}{l}0.262^{* \star *} \\
(0.040)\end{array}$ & $\begin{array}{l}0.141^{\star *} \\
(0.055)\end{array}$ & $\begin{array}{l}0.360^{\star \star \star} \\
(0.058)\end{array}$ & $\begin{array}{l}0.231^{\star * *} \\
(0.034)\end{array}$ & $\begin{array}{l}0.195^{\star \star} \\
(0.062)\end{array}$ & $\begin{array}{l}0.290 \text { *** } \\
(0.047)\end{array}$ \\
\hline $\log (\mathrm{VIX})$ & $\begin{array}{l}-0.023^{* \star *} \\
(0.004)\end{array}$ & $\begin{array}{l}-0.020^{\star * *} \\
(0.005)\end{array}$ & $\begin{array}{l}-0.020^{\star *} \\
(0.007)\end{array}$ & $\begin{array}{l}-0.013^{* *} \\
(0.006)\end{array}$ & $\begin{array}{l}-0.018^{\star *} \\
(0.006)\end{array}$ & $\begin{array}{l}-0.003 \\
(0.009)\end{array}$ \\
\hline Dummy recovery & & & & $\begin{array}{l}-0.001 \\
(0.003)\end{array}$ & $\begin{array}{l}0.007 \\
(0.006)\end{array}$ & $\begin{array}{l}-0.003 \\
(0.005)\end{array}$ \\
\hline Dummy recession & & & & $\begin{array}{l}-0.036^{* \star *} \\
(0.006)\end{array}$ & $\begin{array}{l}-0.012 \\
(0.008)\end{array}$ & $\begin{array}{l}-0.038^{\star * \star} \\
(0.010)\end{array}$ \\
\hline Constant & $\begin{array}{l}0.093^{\star * \star} \\
(0.018)\end{array}$ & $\begin{array}{l}0.068^{\star *} \\
(0.023) \\
\end{array}$ & $\begin{array}{l}0.067^{\star \star} \\
(0.025) \\
\end{array}$ & $\begin{array}{l}0.071^{* *} \\
(0.022) \\
\end{array}$ & $\begin{array}{l}0.067^{\star *} \\
(0.024) \\
\end{array}$ & $\begin{array}{l}0.027 \\
(0.031) \\
\end{array}$ \\
\hline No. Obs. & 616 & 349 & 267 & 616 & 349 & 267 \\
\hline No. instruments & 43 & 17 & 14 & 21 & 21 & 18 \\
\hline No. countries & 39 & 21 & 18 & 39 & 21 & 18 \\
\hline Autocorrelation test, $\mathrm{p}$-value & 0.277 & 0.705 & 0.945 & 0.378 & 0.141 & 0.433 \\
\hline Hansen test, $p$-value & 0.525 & 0.257 & 0.124 & 0.130 & 0.222 & 0.220 \\
\hline $\begin{array}{l}\text { Standard errors in parentheses. }{ }^{* *} p<0.0 \\
\text { Note: The second lag of the GDP growth } \\
1 \text { / Dummy takes the value of } 1 \text { during the } \\
\text { 2/ Dummy takes the value of } 1 \text { during the } \\
3 \text { / Volume of trading partners imports we }\end{array}$ & $\begin{array}{l}{ }^{\star \star} p<0.05,{ }^{\star} p \\
\text { te is included } \\
\text { cession perio } \\
\text { ost-GFC recov } \\
\text { hted by expo }\end{array}$ & $\begin{array}{l}1 \\
\text { regressions } \\
\text { period. } \\
\text { shares. }\end{array}$ & nd (5) to & utocorrelati & & \\
\hline
\end{tabular}

\section{CInternational Monetary Fund. Not for Redistribution}




\begin{tabular}{|c|c|c|c|c|c|c|c|c|c|}
\hline & \multicolumn{3}{|c|}{ Europe } & \multicolumn{3}{|c|}{ Advanced Europe } & \multicolumn{3}{|c|}{ CESEE } \\
\hline VARIABLES & $\begin{array}{c}\text { (1) } \\
\text { Real Credit } \\
\text { Growth }\end{array}$ & $\begin{array}{c}\text { (2) } \\
\text { Real Credit } \\
\text { Growth }\end{array}$ & $\begin{array}{c}\text { (3) } \\
\text { Real Credit } \\
\text { Growth }\end{array}$ & $\begin{array}{c}\text { (4) } \\
\text { Real Credit } \\
\text { Growth }\end{array}$ & $\begin{array}{c}\text { (5) } \\
\text { Real Credit } \\
\text { Growth }\end{array}$ & $\begin{array}{c}6) \\
\text { Real Credit } \\
\text { Growth } \\
\end{array}$ & $\begin{array}{c}(7) \\
\text { Real Credit } \\
\text { Growth }\end{array}$ & $\begin{array}{c}\text { (8) } \\
\text { Real Credit } \\
\text { Growth }\end{array}$ & $\begin{array}{c}\text { (9) } \\
\text { Real Credit } \\
\text { Growth }\end{array}$ \\
\hline Real credit growth $(-1)$ & $\begin{array}{c}0.014 \\
(0.027)\end{array}$ & $\begin{array}{c}0.006 \\
(0.015)\end{array}$ & $\begin{array}{c}0.009 \\
(0.008)\end{array}$ & $\begin{array}{l}-0.032 \\
(0.044)\end{array}$ & $\begin{array}{c}0.013 \\
(0.019)\end{array}$ & $\begin{array}{c}0.009 \\
(0.008)\end{array}$ & $\begin{array}{c}0.048 \\
(0.036)\end{array}$ & $\begin{array}{c}0.042 \\
(0.039)\end{array}$ & $\begin{array}{c}0.062 \\
(0.050)\end{array}$ \\
\hline Regulatory capital ratio & $\begin{array}{l}-0.024 \\
(0.017)\end{array}$ & $\begin{array}{c}0.018 \\
(0.016)\end{array}$ & $\begin{array}{l}-0.012 \\
(0.023)\end{array}$ & $\begin{array}{l}-0.030^{*} \\
(0.017)\end{array}$ & $\begin{array}{l}-0.005 \\
(0.012)\end{array}$ & $\begin{array}{c}0.001 \\
(0.023)\end{array}$ & $\begin{array}{c}0.099 \\
(0.133)\end{array}$ & $\begin{array}{c}0.375 \\
(0.533)\end{array}$ & $\begin{array}{c}2.854 \\
(1.934)\end{array}$ \\
\hline Customer deposit flows/Assets & $\begin{array}{c}0.629^{* \star *} \\
(0.087)\end{array}$ & $\begin{array}{c}0.512^{* * *} \\
(0.105)\end{array}$ & $\begin{array}{c}0.618^{\star * *} \\
(0.093)\end{array}$ & $\begin{array}{c}0.564^{\star \star *} \\
(0.087)\end{array}$ & $\begin{array}{c}0.279^{* * *} \\
(0.108)\end{array}$ & $\begin{array}{c}0.698^{\star * *} \\
(0.131)\end{array}$ & $\begin{array}{c}0.639^{\star \star *} \\
(0.103)\end{array}$ & $\begin{array}{c}0.939^{\star * *} \\
(0.320)\end{array}$ & $\begin{array}{c}0.889^{\star \star *} \\
(0.274)\end{array}$ \\
\hline ROAA & $\begin{array}{l}-0.102 \\
(0.432)\end{array}$ & $\begin{array}{c}2.336 \\
(1.534)\end{array}$ & $\begin{array}{c}0.027 \\
(0.716)\end{array}$ & $\begin{array}{l}-0.132 \\
(0.853)\end{array}$ & $\begin{array}{c}2.743 \\
(1.758)\end{array}$ & $\begin{array}{c}0.120 \\
(0.827)\end{array}$ & $\begin{array}{l}-0.054 \\
(0.551)\end{array}$ & $\begin{array}{c}0.423 \\
(3.551)\end{array}$ & \\
\hline Liquid assets/Total assets & $\begin{array}{l}-0.043 \\
(0.037)\end{array}$ & $\begin{array}{l}-0.010 \\
(0.021)\end{array}$ & & $\begin{array}{l}-0.003 \\
(0.022)\end{array}$ & $\begin{array}{c}0.003 \\
-0.025\end{array}$ & & $\begin{array}{l}-0.071 \\
(0.068)\end{array}$ & $\begin{array}{l}-0.021 \\
(0.070)\end{array}$ & \\
\hline NPL ratio & $\begin{array}{l}-0.284 \\
(0.283)\end{array}$ & $\begin{array}{c}-0.901^{\star *} \\
(0.450)\end{array}$ & $\begin{array}{c}-1.308^{* * *} \\
(0.441)\end{array}$ & $\begin{array}{l}-0.377 \\
(0.342)\end{array}$ & $\begin{array}{l}-0.882^{*} \\
(0.459)\end{array}$ & $\begin{array}{l}-0.654 \\
(0.610)\end{array}$ & $\begin{array}{c}-0.440 \text { ** } \\
(0.176)\end{array}$ & $\begin{array}{l}-1.070^{*} \\
(0.627)\end{array}$ & $\begin{array}{l}-0.781 \\
(0.799)\end{array}$ \\
\hline Bank equity price index & $\begin{array}{l}-0.021 \\
(0.018)\end{array}$ & $\begin{array}{c}0.032^{\star * *} \\
(0.010)\end{array}$ & $\begin{array}{c}0.030^{\star * *} \\
(0.010)\end{array}$ & $\begin{array}{l}-0.005 \\
(0.007)\end{array}$ & $\begin{array}{l}-0.013 \\
(0.011)\end{array}$ & $\begin{array}{c}0.011 \\
(0.016)\end{array}$ & $\begin{array}{c}0.016 \\
(0.011)\end{array}$ & $\begin{array}{l}-0.009 \\
(0.017)\end{array}$ & \\
\hline Real GDP growth & $\begin{array}{c}2.440^{\star * *} \\
(0.374)\end{array}$ & $\begin{array}{c}1.660^{* * *} \\
(0.437)\end{array}$ & $\begin{array}{l}1.907^{* * *} \\
(0.421)\end{array}$ & $\begin{array}{c}2.092^{* * *} \\
(0.563)\end{array}$ & $\begin{array}{c}1.804^{* * *} \\
(0.494)\end{array}$ & $\begin{array}{c}2.918^{* * *} \\
(0.677)\end{array}$ & $\begin{array}{c}1.147^{\star * *} \\
(0.414)\end{array}$ & $\begin{array}{l}1.184^{\star} \\
(0.657)\end{array}$ & $\begin{array}{l}1.304^{\star *} \\
(0.538)\end{array}$ \\
\hline Inflation & $\begin{array}{c}0.439 \\
(0.457)\end{array}$ & $\begin{array}{c}0.166 \\
(0.531)\end{array}$ & $\begin{array}{c}0.768 \\
(0.564)\end{array}$ & $\begin{array}{l}-0.354 \\
(0.250)\end{array}$ & $\begin{array}{l}-0.521^{*} \\
(0.278)\end{array}$ & $\begin{array}{c}0.616 \\
(0.660)\end{array}$ & $\begin{array}{l}-0.162 \\
(0.247)\end{array}$ & $\begin{array}{l}-0.0886 \\
(0.310)\end{array}$ & \\
\hline Recession dummy & $\begin{array}{l}-0.006 \\
(0.066)\end{array}$ & $\begin{array}{c}0.456^{* * *} \\
(0.129)\end{array}$ & $\begin{array}{c}0.261^{\star * *} \\
(0.099)\end{array}$ & $\begin{array}{l}0.0280 \\
(0.036)\end{array}$ & $\begin{array}{c}0.055 \\
(0.060)\end{array}$ & $\begin{array}{l}0.145^{*} \\
(0.075)\end{array}$ & $\begin{array}{l}-0.024 \\
(0.044)\end{array}$ & $\begin{array}{l}-0.251 \\
(0.236)\end{array}$ & \\
\hline Recovery dummy & $\begin{array}{l}-0.096 \\
(0.068)\end{array}$ & $\begin{array}{c}0.027 \\
(0.070)\end{array}$ & $\begin{array}{l}-0.029 \\
(0.060)\end{array}$ & $\begin{array}{l}-0.035^{*} \\
(0.018)\end{array}$ & $\begin{array}{c}-0.147^{\star \star *} \\
(0.054)\end{array}$ & $\begin{array}{c}0.023 \\
(0.039)\end{array}$ & $\begin{array}{c}-0.067^{\star *} \\
(0.030)\end{array}$ & $\begin{array}{c}-0.231^{\star *} \\
(0.115)\end{array}$ & \\
\hline Regulatory capital*Recession dummy & & $\begin{array}{c}-0.183^{* * *} \\
(0.057)\end{array}$ & $\begin{array}{c}-0.120^{\star *} \\
(0.049)\end{array}$ & & $\begin{array}{c}-0.143^{\star *} \\
(0.056)\end{array}$ & $\begin{array}{c}-0.181^{* * *} \\
(0.047)\end{array}$ & & $\begin{array}{l}-0.113 \\
(0.524)\end{array}$ & \\
\hline Deposit flows*Recession dummy & & $\begin{array}{c}0.198 \\
(0.172)\end{array}$ & & & $\begin{array}{c}0.155 \\
(0.194)\end{array}$ & & & $\begin{array}{l}-0.642^{*} \\
(0.363)\end{array}$ & $\begin{array}{l}-0.637 \\
(1.173)\end{array}$ \\
\hline NPL*Recession dummy & & $\begin{array}{c}0.341 \\
(0.598)\end{array}$ & $\begin{array}{c}0.781 \\
(0.511)\end{array}$ & & $\begin{array}{c}0.202 \\
(0.621)\end{array}$ & & & $\begin{array}{c}0.944 \\
(0.618)\end{array}$ & $\begin{array}{c}0.766 \\
(0.688)\end{array}$ \\
\hline Bank equity Index*Recession dummy & & $\begin{array}{c}-0.168^{\star \star \star} \\
(0.062)\end{array}$ & $\begin{array}{l}-0.085 \\
(0.050)\end{array}$ & & $\begin{array}{c}0.003 \\
(0.032)\end{array}$ & & & $\begin{array}{c}0.102 \\
(0.124)\end{array}$ & \\
\hline Regulatory capital*Recovery dummy & & $\begin{array}{l}-0.111^{*} \\
(0.066)\end{array}$ & & & $\begin{array}{l}-0.061 \\
(0.056)\end{array}$ & & & $\begin{array}{l}-0.287 \\
(0.586)\end{array}$ & \\
\hline Deposit flows*Recovery dummy & & $\begin{array}{l}-0.144 \\
(0.153)\end{array}$ & $\begin{array}{l}-0.280^{*} \\
(0.148)\end{array}$ & & $\begin{array}{c}0.179 \\
(0.146)\end{array}$ & & & $\begin{array}{l}-0.458 \\
(0.386)\end{array}$ & \\
\hline ROAA*Recession dummy & & $\begin{array}{l}-3.127^{*} \\
(1.758)\end{array}$ & & & $\begin{array}{l}-3.868 \\
(2.603)\end{array}$ & & & $\begin{array}{l}-0.006 \\
(3.589)\end{array}$ & \\
\hline ROAA*Recovery dummy & & $\begin{array}{c}0.587 \\
(1.794)\end{array}$ & $\begin{array}{c}1.370 \\
(1.508)\end{array}$ & & $\begin{array}{l}-0.265 \\
(2.074)\end{array}$ & & & $\begin{array}{c}1.244 \\
(3.725)\end{array}$ & \\
\hline NPL*Recovery dummy & & $\begin{array}{c}0.915 \\
(0.569)\end{array}$ & $\begin{array}{l}1.275^{\star *} \\
(0.496)\end{array}$ & & $\begin{array}{c}0.768 \\
(0.520)\end{array}$ & & & $\begin{array}{c}0.840 \\
(0.657)\end{array}$ & $\begin{array}{c}0.396 \\
(0.723)\end{array}$ \\
\hline Bank equity Index*Recovery dummy & & $\begin{array}{l}-0.016 \\
(0.025)\end{array}$ & $\begin{array}{l}-0.006 \\
(0.023)\end{array}$ & & $\begin{array}{l}0.039 * * \\
(0.019)\end{array}$ & & & $\begin{array}{c}0.086 \\
(0.055)\end{array}$ & \\
\hline Constant & $\begin{array}{l}0.153^{*} \\
(0.093)\end{array}$ & $\begin{array}{l}-0.046 \\
(0.044)\end{array}$ & $\begin{array}{l}-0.019 \\
(0.040)\end{array}$ & $\begin{array}{c}0.101^{\star * *} \\
(0.034)\end{array}$ & $\begin{array}{c}0.130^{* * *} \\
-0.039\end{array}$ & $\begin{array}{c}0.001 \\
(0.053)\end{array}$ & $\begin{array}{l}0.102^{\star *} \\
(0.045)\end{array}$ & $\begin{array}{l}0.109 * * \\
(0.052)\end{array}$ & $\begin{array}{l}-0.411 \\
(0.370)\end{array}$ \\
\hline No. Obs. & 11,973 & 11,973 & 13,925 & 10,794 & 10,794 & 12,540 & 1,179 & 1,179 & 1,385 \\
\hline No. banks & 3,119 & 3,119 & 3,261 & 2,890 & 2,890 & 3,014 & 229 & 229 & 247 \\
\hline No. instruments & 23 & 47 & 40 & 24 & 46 & 27 & 24 & 45 & 22 \\
\hline Autocorrelation test, $\mathrm{p}$-value & 0.381 & 0.36 & 0.688 & 0.565 & 0.344 & 0.705 & 0.828 & 0.448 & 0.799 \\
\hline Hansen test, p-value & 0.582 & 0.293 & 0.081 & 0.405 & 0.671 & 0.586 & 0.137 & 0.178 & 0.192 \\
\hline
\end{tabular}

\section{CInternational Monetary Fund. Not for Redistribution}


Table 5.1. Models for Bank Profitability and Credit Growth

The table entries represents the coefficients from a linear dynamic panel $(t, i)$ model:

PROFITS $=B^{*}$ [CREDIT GROWTH | CAPITAL | CREDIT RISK | FUNDING RISK | LIQUIDITY RISK | DUMMIES] + e

period: $2000-2015$

Dependent variables:

gint_a gross interest income over total assets

mean st.dev. Independent variables:

nint_a net interest income over total assets

cfee_a commissions and fees over assets

preimp_a preimpairment income over total assets

0.0480 .024 d_gloan_a

credit growth

0.0250 .015 eq_a

$0.0110 .024 \mathrm{nplr}$

0.0130 .017 depr

$0.008 \quad 0.018$ liq

opinc_a operating income over total assets

pretax_a pretax income over total assets

$0.008 \quad 0.019$ size

$0.0050 .016 \mathrm{cri}$

equity over assets

NPL over loans

deposits over total fund

liquid assets over asset:

log of assets

mean

st.dev.

netinc_a net income over total assets

rec

crisis dummy

recovery dummy

\begin{tabular}{|c|c|c|c|c|c|c|c|}
\hline \multicolumn{8}{|l|}{ System GMM, 2 lags } \\
\hline 1 & 2 & 3 & 4 & 5 & 6 & 7 & 8 \\
\hline$\downarrow X \backslash Y \rightarrow$ & gint_a & nint_a & cfee_a & preimp_a & opinc_a & pretax_a & netinc_a \\
\hline I. & $0.381^{\star \star *}$ & $0.341^{\star \star *}$ & $0.587^{\star *}$ & 0.103 & 0.108 & 0.107 & 0.074 \\
\hline 12. & -0.075 & -0.006 & 0.053 & 0.065 & 0.028 & -0.02 & -0.027 \\
\hline d_gloan_a & $0.08^{\star * *}$ & $0.037^{* * *}$ & $0.025^{*}$ & $0.024^{\star *}$ & $0.032^{\star *}$ & $0.022^{\star *}$ & $0.017^{*}$ \\
\hline eq_a & -0.056 & $-0.312^{*}$ & -0.327 & -0.155 & 0.151 & 0.029 & -0.017 \\
\hline nplr & $0.394^{\star \star}$ & $0.265^{*}$ & $0.309 *$ & -0.066 & 0.121 & -0.029 & -0.07 \\
\hline depr & -0.381 & 0.108 & 0.269 & $0.337^{*}$ & -0.072 & 0.05 & 0.034 \\
\hline liq & 0.132 & -0.197 & $-0.366^{\star}$ & $-0.404^{*}$ & 0.127 & -0.065 & -0.046 \\
\hline size & $-0.013^{*}$ & $-0.007^{*}$ & -0.004 & 0.011 & -0.002 & -0.005 & -0.006 \\
\hline cri & -0.146 & 0.024 & 0.018 & 0.145 & 0.038 & -0.112 & -0.152 \\
\hline cri_d_gloan_a & $-0.161^{\star \star}$ & -0.045 & $-0.079 *$ & 0.008 & -0.034 & $-0.075^{\star \star}$ & $-0.068^{\star *}$ \\
\hline cri_eq_a & 0.035 & -0.035 & 0.363 & 0.05 & -0.137 & 0.073 & 0.011 \\
\hline cri_nplr & $-0.393^{\star \star}$ & -0.201 & $-0.349 * \star$ & 0.111 & -0.27 & -0.161 & -0.091 \\
\hline cri_depr & 0.512 & 0.058 & $-0.454^{*}$ & -0.243 & 0.054 & -0.02 & 0.057 \\
\hline cri_liq & -0.495 & 0 & $0.601^{\star \star}$ & 0.276 & -0.07 & 0.068 & -0.014 \\
\hline cri_size & 0.006 & -0.002 & -0.004 & -0.008 & 0 & 0.004 & 0.006 \\
\hline rec & -0.059 & 0.176 & -0.182 & 0.101 & -0.083 & $-0.254^{\star *}$ & $-0.268^{\star * *}$ \\
\hline rec_d_gloan_a & 0.002 & 0.015 & 0.007 & -0.032 & $-0.042^{*}$ & -0.019 & -0.017 \\
\hline rec_eq_a & 0.095 & -0.067 & 0.318 & -0.024 & $-0.344^{*}$ & -0.073 & -0.1 \\
\hline rec_nplr & -0.182 & -0.136 & -0.312 & 0.109 & -0.249 & -0.096 & -0.019 \\
\hline rec_depr & 0.265 & -0.05 & -0.305 & -0.269 & 0.117 & 0.022 & 0.077 \\
\hline rec_liq & -0.221 & 0.113 & 0.407 & 0.299 & -0.122 & 0.021 & -0.047 \\
\hline rec_size & 0 & -0.01 & 0.006 & -0.005 & 0.006 & $0.012^{* *}$ & $0.012^{* * *}$ \\
\hline cons & $0.456^{\star *}$ & $0.217^{*}$ & 0.139 & -0.172 & 0.007 & 0.119 & 0.145 \\
\hline Number of observations & 15,595 & 15,595 & 15,595 & 15,595 & 15,595 & 15,595 & 15,595 \\
\hline Number of banks & 3,454 & 3,454 & 3,454 & 3,454 & 3,454 & 3,454 & 3,454 \\
\hline Number of instruments & 44 & 44 & 44 & 44 & 56 & 62 & 62 \\
\hline$A R(3)$ test $p$-value & $42 \%$ & $96 \%$ & $63 \%$ & $36 \%$ & $57 \%$ & $37 \%$ & $35 \%$ \\
\hline Hansen test $p$-value & $61 \%$ & $86 \%$ & $97 \%$ & $54 \%$ & $90 \%$ & $55 \%$ & $61 \%$ \\
\hline
\end{tabular}

CInternational Monetary Fund. Not for Redistribution 
Table 5.2. Models for Bank Profitability and Credit Growth: Standardized Regressions

The table entries represents the coefficients from a linear dynamic panel $(t, i)$ model:

PROFITS $=B^{\star}[$ CREDIT GROWTH $\mid$ CAPITAL $\mid$ CREDIT RISK | FUNDING RISK | LIQUIDITY RISK | DUMMIES] + e

period: $1999-2015$

Dependent variables:

sgint_a gross interest income over total ass

snint_a net interest income over total asset:

mean

1.0

1.0

1.0

scfee_a

spreimp_a

sopinc_a

spretax_a

snetinc_a commissions and fees over assets

preimpairment income over total as

operating income over total assets

pretax income over total assets

net income over total assets

st.dev.
1.0
1.0
1.0
1.0
1.0
1.0
1.0

Independent variables: sd_gloa credit growth

seq_a equity over assets

snplr NPL over loans

sdepr deposits over total funding

sliq liquid assets over assets

ssize log of assets

cri crisis dummy

rec recovery dummy

\begin{tabular}{|c|c|c|c|c|c|c|c|}
\hline \multicolumn{8}{|l|}{ System GMM, 2 lags } \\
\hline 1 & 2 & 3 & 4 & 5 & 6 & 7 & 8 \\
\hline$\downarrow X \backslash Y \rightarrow$ & sgint_a & snint_a & scfee_a & spreimp_a & sopinc_a & spretax_a & snetinc_a \\
\hline I. & $0.38^{\star \star \star}$ & $0.33^{\star *}$ & $0.49 * *$ & 0.1 & 0.1 & 0.07 & 0.08 \\
\hline 12 & -0.09 & 0.05 & 0.06 & 0.07 & 0.01 & -0.04 & -0.03 \\
\hline sd_gloan_a & $0.5^{\star * *}$ & $0.4^{*}$ & $0.1^{\star *}$ & $0.11^{*}$ & $0.16^{*}$ & $0.33^{*}$ & $0.29 *$ \\
\hline seq_a & -0.28 & 1.1 & -0.32 & -0.79 & 0.93 & 0.72 & -0.04 \\
\hline snplr & $1.51^{*}$ & 1.31 & $1.13^{*}$ & -0.26 & 0.44 & -0.17 & -0.29 \\
\hline sdepr & -3.82 & -0.17 & $3.02^{* *}$ & $5.15^{\star *}$ & -0.89 & -0.72 & 0.07 \\
\hline sliq & 2.47 & 0.47 & $-3.15^{\star *}$ & $-5.08^{* *}$ & 1.42 & 1.37 & 0.3 \\
\hline ssize & -0.92 & $2.4^{\star \star}$ & 0.11 & 0.9 & -0.63 & -0.62 & $-1.25^{\star \star}$ \\
\hline cri & -0.58 & -0.49 & 0.08 & -0.03 & -0.24 & 0.14 & 0.1 \\
\hline cri_sd_gloan_a & $-1.24^{\star \star \star}$ & -0.08 & $-0.25^{*}$ & -0.2 & $-0.39 *$ & $-0.64^{*}$ & $-0.6^{\star}$ \\
\hline cri_seq_a & -0.04 & -1.03 & 0.61 & 0.34 & -0.39 & 0.25 & 0.2 \\
\hline cri_snplr & $-2.02^{\star \star \star}$ & -1.08 & $-1.33^{\star *}$ & 0.22 & -1.28 & -0.89 & -0.58 \\
\hline cri_sdepr & 5.79 & 2.24 & $-3.39 * *$ & $-3.1^{\star}$ & 1.06 & -0.31 & 0.74 \\
\hline cri_sliq & -6 & -2.79 & $3.41^{*}$ & 2.92 & -1.05 & 0.42 & -0.67 \\
\hline cri_ssize & 1.43 & -1.79 & -0.22 & -0.46 & 0.52 & 0.76 & $1.38^{* *}$ \\
\hline rec & $-0.66^{*}$ & -0.62 & -0.01 & -0.41 & -0.27 & -0.07 & -0.17 \\
\hline rec_sd_gloan_a & -0.12 & -0.25 & 0.02 & -0.01 & -0.11 & -0.3 & $-0.3^{*}$ \\
\hline rec_seq_a & -0.34 & -0.65 & 0.58 & 0.27 & -1.07 & -0.8 & -0.58 \\
\hline rec_snplr & -0.92 & -1.15 & -1.05 & 0.39 & -1 & -0.47 & -0.09 \\
\hline rec_sdepr & 3.58 & -2.02 & $-3.03^{*}$ & $-3.84^{\star \star}$ & 0.57 & 0.4 & 1.14 \\
\hline rec_sliq & -3.75 & 0.72 & $3.16^{*}$ & $3.41^{\star}$ & -0.27 & -0.04 & -0.98 \\
\hline rec_ssize & 0.81 & -1.31 & 0.04 & 0.67 & 1.03 & $1.49 *$ & $1.86^{* *}$ \\
\hline _cons & 0.25 & 0.23 & -0.04 & -0.02 & 0.24 & -0.04 & 0.04 \\
\hline Number of observations & 15,595 & 15,595 & 15,595 & 15,595 & 15,595 & 15,595 & 15,595 \\
\hline Number of banks & 3,454 & 3,454 & 3,454 & 3,454 & 3,454 & 3,454 & 3,454 \\
\hline Number of instruments & 44 & 41 & 44 & 50 & 62 & 49 & 72 \\
\hline$A R(3)$ test $p$-value & $40 \%$ & $38 \%$ & $33 \%$ & $42 \%$ & $93 \%$ & $48 \%$ & $43 \%$ \\
\hline Hansen test $p$-value & $70 \%$ & $44 \%$ & $47 \%$ & $93 \%$ & $37 \%$ & $49 \%$ & $82 \%$ \\
\hline
\end{tabular}




\section{Appendix I. Economic Hypotheses about Post-Financial-Crisis Recoveries}

\section{Economic theory suggests that post-financial-crisis recoveries can often be weak, long,} and creditless. Credit-fueled booms that often precede financial crises are usually large, persistent, and driven by exuberant expectations. The bigger the boom, the larger the correction when the bubble busts, hence the longer the recovery. Moreover, the smaller the precautionary equity cushions of the groups most affected, the larger the shifts in asset prices, their balance sheets, and the perceived real natural interest rate. These shifts are needed to reconcile post-crisis savings and investment decisions. Both the corrective powers of the economy as well as the quality and timeliness of policy actions to facilitate the adjustment can influence the length of the recovery. The initial recovery is more likely to be creditless, if the debt is high, the correction large, and cushions small, hence adversely affecting both the willingness and ability to borrow and lend. This box lists economic theories supporting these assertions.

\section{Exuberant expectations followed by shattered confidence are at the core of most boom-} bust theories. Expectations are the best proxy to deal with incomplete and imperfect information in the real world. Learning through trial and error, however, causes a fog of risk and uncertainty (Knight, 1921), but also exuberance that can generate self-fulfilling erroneous expectations. Such expectations can fuel bubbles and cause Manias, Panics, and Crashes (Kindleberger, 1978). This phenomenon has also been described by Minsky's Financial Instability Hypothesis (Randall, 2016), while Guttentag and Herring's (1984) Disaster Myopia demonstrates that large cycles can be caused by rare but important triggers. Myopic behavior is often seen as irrational after the fact (e.g., Yao and Zhang, 2011), but may actually be rational under certain constraints, including non-linear time preferences, e.g., Strotz (1955), Laibson (1997), and Bordalo, Gennaiola, and Shleifer (2016).

\section{Most of these theories identify three distinct phases: boom, bust, and recovery}

(Figure). During the boom, heterogeneous rational agents see that their more aggressive competitors prevail, supported by overshooting of asset prices due to inelastic supply, new technology, new regulations, etc. More and more investors join the rally, convinced that This Time is Different (Reinhart and Rogoff, 2009). The bubble bursts when a trigger event exposes the unrealistic prospects, typically based on expectations of future price increases rather than on the net present value of realistic returns from the functions that the asset performs. During the recovery, expectations are recalibrated and balance sheets are adjusted, which sometimes cause asset price deflation and excessive pessimism. Credit policies may be introduced to 
support the recovery (IMF, 2013). Ultimately, a "new normal" emerges. Agents that rely on own resources may increase their consumption and investments, when they think that prices have bottomed. For the indebted, the deleveraging gradually comes to an end, allowing for renewed optimism that strengthens the recovery. Lending then resurfaces. As the perceived risks fade, crisis-prevention safeguards, put in place in reaction to the collapse, may be deemed an obstacle for the recovery. If reduced, or even eliminated without otherwise addressing the potential risks, the starting conditions for the next cycle are created.

\section{Severe boom-bust cycles are typically amplified by excessive debt provided by an} unhinged financial sector. Irving Fisher (1933, page 341) noted that "...over-confidence seldom does any great harm except when, as, and if, it beguiles its victims into debt." While financial intermediaries can facilitate growth, they can also amplify a bubble, being convinced that they can diversify and cover their risk by collateral. As the asset prices and collateral values increase, they lend even more, creating a financial accelerator (Kiyotaki and Moore, 1997; Bernanke, Gertler and Gilchrist, 1999). Furthermore, financial innovation may temporarily result in neglected risks (Gennaioli et al., 2012). Distorted short-term incentives of bank managers and shareholders can further boost unsustainable lending. Large banks feel that they are "too big to fail" and take excessive individual and systemic risks (Laeven et al. 2014). During the recovery phase, credit institutions may, as a whole, instead become: (i) less willing to lend, due to excessive pessimism, as the more aggressive ones have suffered large losses; or, (ii) less able to lend, since the losses have absorbed their regulatory capital, made funding prohibitively expensive for weaker banks, and made them focus on recovering non-performing loans. Finally, until there is clarity about new "financial-crisis-prevention regulation," many banks may put lending to new projects and clients on hold.

\section{The size of equity cushions and the efficiency of debt-recovery processes may affect the} length of the recovery and whether it will be creditless initially. Adequate cushions can reduce the risks for fire sales as well as the motivation to rebuild precautionary savings following a collapse. Households may target a precautionary savings buffer stock (Carroll et al., 1992), which depends on liquidity constraints (Deaton, 1991). For instance, the targeted savings - combined with a large decline in real estate prices, the most important asset for most households (Mian and Sufi, 2014) —will usually have been diluted during a collapse. This can, in addition to poorer employment prospects, cause a further contraction in demand by the less wealthy households. ${ }^{2}$ Companies give priority to survival; thus, they reduce debt and rebuild equity, even when the expected net present value of new investments is positive. If a critical mass perceive that they have insufficient buffers, growth and lending may be

\footnotetext{
${ }^{1}$ Mian and Sufi's (2014) House of Debt offers a seminal description of how easy mortgage credit in the USA, particularly to vulnerable households, contributed to the housing bubble, bust, and slow recovery.

${ }^{2}$ Mian et al. (2015) found, based on a panel of 30 countries during 1960 to 2012, that a 6 percentage-point increase in household debt over GDP over three years predicts a 2 percentage-point lower GDP in the subsequent three years.
} 
further suppressed and cause a more severe balance sheet recession (Koo, 2003, 2011). Country-specific factors affect the magnitude and distribution of buffers. ${ }^{3}$ The larger the cushions for those affected and the easier to rebuild them, the faster the recovery and renewed demand for credit.

\section{Many have tried to model severe debt-fueled boom and busts á la Fisher (debt-deflation), Minsky (financial sector instability), and Koo (balance sheet recession).} Eggertsson and Krugman (2012) offer an interesting reconciliation of these approaches capturing private sector debt-overhang. Their New Keynesian-style model allows for some agents to become over-indebted. After a shock requiring deleveraging hits, aggregate demand tanks. Monetary policy can alleviate modest shocks, but in case of severe recessions, the zero-lower bound is quickly reached. Even with central banks promising future inflation, the resulting negative real interest rates may still not be able to clear the markets. Instead, an expansionary fiscal stance may be needed to temporarily alleviate sluggish demand, while the balance sheet re-adjustment takes place. The fiscal impact is usually bigger during a recession and will not be fully crowded out. The impact, however, will depend on: (i) how well the over-indebted agents are being relieved; and (ii) how the measure is financed, i.e. how those taxed today or in the future adjust their demand today. The model also derives that productivity-enhancing structural policies can worsen debt dynamics by further subduing aggregate demand in case of a liquidity trap. This may, however, stem from the fact that the model does not fully capture that structural policies making the economy more efficient can potentially boost the perceived real-risk-adjusted return-i.e., increase the marginal propensity to invest and consume - and thus advance the recovery.

\footnotetext{
${ }^{3}$ Mitman, Krueger, and Perri (2016) find that recessions are worse in case of a less-equal wealth distribution.
} 


\section{APPENDiX II: SELECTED DATA ISSUES}

\section{A. Countries and Period Covered}

Country coverage includes most European countries, with additional countries included in Section II in the control group that has experienced prior recessions. The European countries are split into: (i) Advanced Economies (AE), which are further divided into (a) Eurozone and (b) non-Eurozone; and (ii) Central European and South Eastern European Countries (CESEE). Due to data limitations, Belarus, Luxembourg, Moldova, San Marino, and Ukraine were excluded. In Section II, seventeen non-European countries were also included in the control group to compare post-GFC European recoveries to previous recoveries (Table AI.1). The analyzed period is 1999-2016 (2015 for Sections IV and V relying on individual bank data).

Table AI.1: Country Groups used in Section II

\begin{tabular}{|c|c|c|c|c|c|c|c|}
\hline & $\begin{array}{l}\text { Euro area - } \\
\text { advanced }\end{array}$ & & $\begin{array}{l}\text { Other European - } \\
\text { advanced }\end{array}$ & & $\begin{array}{l}\text { Central, Eastern, and } \\
\text { Southeastern European }\end{array}$ & & Other \\
\hline 1 & Austria * & 1 & Denmark * & 1 & Albania & 1 & Argentina * \\
\hline 2 & Belgium & 2 & Iceland * & 2 & Bosnia \& Herzegovina & 2 & Australia * \\
\hline 3 & Cyprus * & 3 & Israel * & 3 & Bulgaria & 3 & Brazil * \\
\hline 4 & Finland * & 4 & Norway * & 4 & Croatia & 4 & Canada * \\
\hline 5 & France * & 5 & Sweden * & 5 & Czech Republic & 5 & China, P.R.:Mainland \\
\hline 6 & Germany * & 6 & Switzerland * & 6 & Estonia & 6 & China, P.R.:Hong Kong * \\
\hline 7 & Greece * & 7 & United Kingdom * & 7 & Hungary & 7 & India * \\
\hline 8 & Ireland * & & & 8 & Kosovo & 8 & Indonesia \\
\hline 9 & Italy * & & & 9 & Latvia & 9 & Japan * \\
\hline 10 & Malta * & & & 10 & Lithuania & 10 & Korea, Republic of * \\
\hline 11 & Netherlands * & & & 11 & Macedonia, FYR & 11 & Malaysia * \\
\hline 12 & Portugal * & & & 12 & Montenegro & 12 & Mexico * \\
\hline \multirow[t]{6}{*}{13} & Spain * & & & 13 & Poland & 13 & Philippines * \\
\hline & & & & 14 & Romania & 14 & Singapore * \\
\hline & & & & 15 & Russian Federation * & 15 & South Africa * \\
\hline & & & & 16 & Serbia, Republic of & 16 & Turkey * \\
\hline & & & & 17 & Slovak Republic & 17 & United States * \\
\hline & & & & 18 & Slovenia & & \\
\hline
\end{tabular}

\section{B. Data Sources}

The IMF's International Financial Statistics (IFS) and World Economic Outlook (WEO) database are the primary sources of the macro data. Please see Annexes II.1 to II.4 for sources of the time series used in Sections II to V, respectively.

Data on country-level total credit and bank lending to the non-financial private sector are from the BIS's database on Total Credit to the Non-Financial Sector and the IMF's IFS database. The BIS database provides a breakdown of both total credit and lending by 
domestic banks to all other sectors of the economy and non-residents. ${ }^{1,2}$ It covers 22 European countries. For the remaining countries, data are from the IFS database (see Annex II. 1 for details). Credit is measured as the change in stocks. (It would have been preferable to use flows of newly extended credit, but long consistent time series are not available.)

Individual bank data used in sections III and V are from the Fitch Connect database. ${ }^{3}$ After removing data outliers (see Section C), the sample includes about 6,000-7,000 bank data points per year in 1999-2015. Preference is given to unconsolidated bank statements. ${ }^{4}$ Bank residency is based on the location of individual banks, including subsidiaries but not branches. For instance, a subsidiary of an Italian bank in Poland is treated as a Polish entity. However, if the subsidiary in Poland has branches in other countries, they could be reported as part of the subsidiary in Poland.

\section{Data Cleaning}

The top and bottom one percent outliers were removed from the sample. In Section IV and $\mathrm{V}$, implausible observations of individual bank data, indicating quality problems, were also removed from the regressions. In Section III, which uses country-level data, extreme values for credit growth, credit-to-GDP ratio, credit impulse, and public consumption were excluded from the regressions. The thresholds used to eliminate extreme values were the top and bottom 1 percent of their distribution for the sample of all countries, and the cut-off values are shown in Table AII.2. ${ }^{5}$ No extreme values above/below the $1^{\text {st }}$ and $99^{\text {th }}$ percentile were detected for external demand and the general government balance-to-GDP ratio.

Table AII.2. Thresholds for Elimination of Outliers in Section III

\begin{tabular}{|l|l|l|l|l|}
\hline Variable (not in \%) & $\begin{array}{l}\mathbf{1}^{\text {st }} \\
\text { percentile }\end{array}$ & $\begin{array}{l}\mathbf{9 9}^{\text {th }} \\
\text { percentile }\end{array}$ & $\begin{array}{l}\text { Min. } \\
\text { value }\end{array}$ & $\begin{array}{l}\text { Max. } \\
\text { value }\end{array}$ \\
\hline Credit growth & -0.225 & 0.471 & -0.540 & 0.984 \\
\hline Public consumption growth rate & -0.102 & 0.116 & -0.475 & 0.303 \\
\hline Credit-to-GDP & 0.086 & 2.460 & 0.047 & 3.122 \\
\hline Credit impulse & -0.461 & 0.374 & -0.782 & 0.716 \\
\hline
\end{tabular}

\footnotetext{
${ }^{1}$ The database is available on: http://www.bis.org/statistics/totcredit.htm.

${ }^{2}$ Domestic bank credit to the private sector is only part of private non-financial sector debt. For instance, when many CESEE countries took measures to contain domestic bank lending during the boom, some banking groups moved the lending to part of the group located abroad. These so-called externalized loans were substantial in some countries. Also, financing from non-bank financial companies-leasing companies, consumer credit companies, inter-company loans from foreign parents etc.- -were sizable in some countries.

${ }^{3}$ For details about this database, see: http://www.fitchconnect.com .

${ }^{4}$ That is, unconsolidated statements are used if both the unconsolidated and consolidated statements are available. However, a consolidated statement is used if it is the only available for a given bank in a given year.
}

${ }^{5}$ All of the extreme values were in CESEE countries. No extreme values above/below the $1^{\text {st }}$ and $99^{\text {th }}$ percentile were detected in the sample of AE countries. 


\section{Selected Definitions and Concepts}

The Bry and Boschan (1971) algorithm dates the business cycle peaks and troughs across countries using the original series of real GDP per capita data in levels. The algorithm looks for a local minimum in the annual series, which is labeled as a trough. The preceding local maximum is then labeled as a peak.

\section{Laeven and Valencia's definition of a systemic banking crisis is used to categorize a} financial crisis. ${ }^{6}$ The following two conditions must be met to qualify for a banking crisis. First, Laeven and Valencia (2012, page 4) note that: (i) "Significant sign of financial stress in the banking system (as indicated by significant bank runs, losses in the banking system, and/or bank liquidations." and (ii) "Significant banking policy intervention measures in response to significant losses in the banking system." This definition implies that some countries may not have had a systemic banking crisis, if they have not met three of the six sub-conditions being "significant," although they may still have experienced severe financial tensions, like Hungary in 2008. In addition, a few financial crisis dates were adjusted from t, the year of the crisis in Laeven and Valencia to $\mathrm{t}-1$ or $\mathrm{t}+1$ to align the crisis date with the business cycle. Moreover, we added late financial crises (Cyprus, Slovenia) to Laeven and Valencia's list.

The NPL ratio was used as a proxy for loan quality. This ratio reflects past credit policies. A high NPL ratio could have consequences for market access to funding and could imply that bank management is preoccupied with debt recoveries rather than new lending. The unprovisioned part of the NPLs may be a better proxy for a bank's ability to extend new loans, particularly if the regulatory capital is close to the minimum requirements. Hence, it is a more forward looking indicator, but data availability limited its use.

\footnotetext{
${ }^{6}$ Their database covers systemic banking, currency, and sovereign debt crisis during the period 1970-2011. A banking crisis is considered systemic if there are significant bank runs, losses in the banking system; and/or bank liquidations; as well as significant banking policy interventions.
} 


\section{ANNEX II.1. DESCRIPTION OF DATA USED IN SECTION II}

Gross domestic product (current prices; constant prices; and in U.S. dollars). Annual time series data obtained from $W E O$.

Private consumption expenditure (constant prices). Annual time series data obtained from WEO.

Gross fixed capital formation (nominal prices; constant prices). Annual time series data obtained from $W E O$. South Africa's gross fixed capital formation data were extended from the Economic Database of the Federal Reserve Bank of St. Louis (FRED). ${ }^{1}$

Current account balance (in U.S. dollars). Annual time series data obtained from WEO. United States' current account data were extended from FRED.

External demand. Volume of total imports of goods and services of country's trading partners weighted by country's export shares. Annual time series data obtained from the IMF's Global Economic Environment (GEE) indicators (TM_R_WX or TM_R_PCH_WX).

Excess credit. Quarterly time series on bank credit to the private non-financial sector obtained from the BIS's database on Total Credit to the Non-Financial Sector. BIS bank data series were extended in some cases by applying growth rates from BIS total credit series. For those countries not included the BIS database, a quarterly time series on depository institution claims on private sector was obtained from IFS. Annual data was then derived from the quarterly series.

Population. Annual time series data obtained from IFS. Population data for Kosovo and Macedonia were augmented from the World Bank Databank.

Consumer price index. Annual time series data obtained from WEO. Argentina's consumer price index data were extended from FRED.

Total credit and bank lending to the non-financial private sector are from the BIS's database on Total Credit to the Non-Financial Sector and the IMF's IFS database. Credit includes loans, debt securities, and currency \& deposits. The BIS database covers 22 countries in our sample. ${ }^{2}$ For the remaining countries, we use consolidated claims on private sector (line NSRF_22d and SRF_22d) from the IMF's IFS database.

\footnotetext{
${ }^{1}$ For details, see: https://fred.stlouisfed.org/.

${ }^{2}$ Austria, Belgium, Switzerland, Czech Republic, Germany, Denmark, Spain, Finland, France, United Kingdom, Greece, Hungary, Ireland, Israel, Italy, Luxembourg, Netherlands, Norway, Poland, Portugal, Sweden, and Turkey.
} 


\section{ANNEX II.2. DESCRIPTION OF DATA USED IN SECTION III}

Nominal gross domestic product. Annual time series data from WEO.

Real gross domestic product. Annual time series data from $W E O$.

Public sector consumption in real terms. Annual time series data from WEO.

General government balance (net lending/borrowing). Annual time series data from WEO.

External demand. Volume of total imports of goods and services, percent change, of country's trading partners weighted by country's export shares. Annual time series data GEE.

Volatility index (VIX). The Chicago Board Options Exchange (CBOE) Volatility Index, which shows the market's expectation of near-term volatility. Annual averages were created using daily data. Data are available at: http://www.cboe.com/micro/vix/historical.aspx.

Interest rate. The cost of capital was proxied by using country's key policy rate. The data were mainly obtained from Haver Analytics. Gaps in the data for certain countries were covered, as much as possible, using information from IFS using the policy rate.

Private gross fixed capital formation (in real terms). Annual time series data from $W E O$. Data for a group of countries was generated by imposing the share of nominal private GFCF in total GFCF to the time series of real GFCF. ${ }^{1}$

Total credit and bank lending to the non-financial private sector are from the BIS's database on Total Credit to the Non-Financial Sector and the IMF's IFS database. Credit covers core debt, defined as loans, debt securities, and currency \& deposits. In addition, it adjusts for structural breaks. It covers 22 countries in our sample. For the remaining countries, we use consolidated claims on private sector (line NSRF_22d and SRF_22d) from the IMF's IFS database.

\footnotetext{
${ }^{1}$ Germany, Sweden, Albania, Bulgaria, Lithuania, Poland, Denmark, San Marino, Norway, Ireland, Malta, Spain, Cyprus, Latvia, Hungary, Slovenia.
} 


\section{ANNEX II.3. DESCRIPTION OF DATA USED IN SECTION IV}

Macroeconomic variables (MACRO) were from $W E O$ and included:

- GDP growth, i.e. percentage change of real gross domestic product.

- Average inflation, i.e. the average annual change of the CPI.

Bank fundamentals (B_FUND) were from Fitch Connect and included:

- Deposit growth, defined as the annual change of domestic deposits scaled by assets.

- Profitability, proxied by the annual return to assets.

- Capitalization, defined as total bank capital scaled by assets.

- Bank liquidity, proxied by liquid assets as a ratio of total assets.

- Loan quality, proxied by non-performing loan ratio as a percent of gross loans.

DumRecession is dummy variable taking a value of 1 during recessions and 0 otherwise. Recession periods are dated given the peaks and troughs in the level of real GDP.

DumRecovery is a dummy variable taking a value of 1 during recoveries and 0 otherwise. Recoveries are defined as periods following the recessions. 


\section{ANNEX II.4. DESCRIPTION OF DATA USED IN SECTION V}

Income bank data are from Fitch Connect and scaled by total assets of the respective banks:

- Gross interest income, i.e. interest income before any deductions.

- Net interest income, i.e. gross interest income minus gross interest costs.

- Commission and fee income are derived from the lending volume in a given year but also include fees from trading activities.

- Pre-impairment income, i.e. operating income before provisions.

- Operating income, i.e. gross income minus operating expenses, depreciation and amortization.

- Pretax income, net income before taxation.

- Net income, i.e. revenues minus costs of doing business, including interest, depreciation, taxes, and other expenses.

Explanatory bank variables are also from Fitch Connect and scaled:

- $\quad L O A N$ is credit growth (the change in gross loans over assets).

- CAPITAL is equity over assets. An alternative specification used the Tier 1 capital ratio (Tier 1 capital over risk-weighted assets).

- $\quad$ CREDIT is a measure of credit risk, namely the gross NPL ratio. Explored alternatives include the net NPL ratio and the coverage ratio (the stock of loan loss provisions over NPLs).

- FUNDING is a measure of funding risk, the share of deposits in total funding. The loan to deposit ratio was explored as well.

- LIQUIDITY is liquid assets over total assets, as reported by Fitch Connect.

- $\quad$ TYPE is a dummy variable for the type of bank specialization 


\section{REFERENCES}

Abdoun, Ramdane, Shekhar Aiyar, Bartek, Augustyniak, Tom Dorsey, Christian Ebeke, Greetje Everaert, Christoph Klingen, Julie Kozack, Ruy Lama, Weicheng Lian, Sergejs Saksonovs, Xiaobo Shao, Gabriel Srour, Eugene Tereanu, Felix Winnekens, Astou Diouf, and Hongyan Zhao, (2014), Baltic Cluster Report: Selected Issues, IMF Country Report No 14/117, International Monetary Fund, Washington DC.

Abiad, Abdul, Giovanni Dell'Ariccia, and Bin Li, 2011, “Creditless Recoveries”, IMF Working Paper, WP/11/58, International Monetary Fund, Washington DC.

Almarzoqi, A. and S. B. Naceur, 2015 "Determinants of Bank Interest Margins in the Caucasus and Central Asia" IMF Working Paper WP/15/87

Arellano, M. and O. Bover, 1995 "Another Look at the Instrumental-Variable Estimation of Error-Components Models.” Journal of Econometrics, 68, 29-51.

Bakker, Bas B., and Leslie Lipschitz, 2014, "Conventional and Insidious Macroeconomic Balance-Sheet Crises," IMF Working Paper No. WP/14/160, International Monetary Fund, Washington DC.

Bech, Morten L.; Leonardo Gambacorta; and Enisse Kharroubi, 2012, "Monetary policy in a downturn: Are financial crises special?” BIS Working Paper No. 388, Bank for International Settlement, Basel.

Beck, Thorsten, and Ross Levine, 2000, "Stock Markets, Banks and Growth: Correlation or Causality?," World Bank mimeo, 2000.

Beck, Thorsten, Ross Levine, and Norman Loayza, 2000, "Finance and the Sources of Growth," Journal of Financial Economics 58 (2000), 261-300.

Berger, Helge; Thomas Dowling; Sergi Lanau; Weicheng Lian; Mico Mrkaic; Pau Rabanal; and Marzie Taheri Sanjani, 2015, "Steady as She Goes-Estimating Potential Output During Financial "Booms and Busts" IMF Working Paper No. WP/15/233, International Monetary Fund, Washington DC.

Bernanke, Ben S., Mark Gertler, and Simon Gilchrist, 1999, "The Financial Accelerator in a Quantitative Business Cycle Framework," Chapter 21 in Handbook of Macroeconomics, Vol. 1, part C, pages 1341-1393. Elsevier B.V.

Biggs, Michael; Thomas Mayer; and Andreas Pick, 2009, "Credit and Economic Recovery," DNB Working Paper, No. 218, July, De Nederlandsche Bank, Amsterdam

Biggs, Michael, Thomas Mayer, and Andreas Pick (2010), "Credit and Economic Recovery: Demystifying Phoenix Miracles" Mimeo. 
Bijsterbosch, Martin, and Tatjana Dahlhaus, 2011, "Determinants of Credit-Less Recoveries,” ECB Working Paper No. 1358, European Central Bank, Frankfurt. June

Blanchard, Olivier; Eugenio Cerutti; and Lawrence Summers, 2015, "Inflation and Activity Two Explorations and their Monetary Policy Implications" IMF Working Paper No. WP/15/230, International Monetary Fund, Washington DC.

Blundell, Richard, and Stephen Bond, 1998 "Initial Conditions and Moment Restrictions in Dynamic Panel Data Models.” Journal of Econometrics, 87, 115-143.

Bodnár, Katalin, Zsolt Kovalszky, and Emese Kreiszné Hudák, 2015, "Recovery from Crises and Lending," in Financial and Economic Review, Vol. 13, Issue 4, pp. 57-85. Hungarian National Bank (Magyar Nemzeti Bank), Budapest. https://ssrn.com/abstract $=2756908$

Bordalo, Pedro; Nicola Gennaiola; and Andrei Shleifer, 2016, "Diagnostic Expectations and Credit Cycles," NBER Working Paper No. 22266, The National Bureau of Economic Research.

Bordo, Michael D; and Joseph G. Haubrich, 2009, "Credit Crises, Money and Contractions: An Historical View," NBER Working Paper No. 15389, National Bureau of Economic Research, Cambridge.

Borio, C., L. Gambarcorta, and B. Hofmann, 2015 "The influence of monetary policy on bank profitability" BIS Working Paper No 514.

Braun, Matias and Borja Larrain, 2005, "Finance and Business Cycle: International, Inter-Industry Evidence," Journal of Finance, American Finance Association, vol. 60(3), 1097-1128, 06.

Calvo, Guillermo A.; Alejandro Izquierdo; and Ernesto Talvi, 2006A, "The Economics of Sudden Stops in Emerging Economies, American Economic Review, Vol. 96. No. 2, pp. $405-410$.

Calvo, Guillermo A.; Alejandro Izquierdo; and Ernesto Talvi, 2006B, "Phoenix Miracles in Emerging Markets: recovering without Credit from Systemic Banking Crises, Working Paper No. 570, Inter-American Development Bank.

Calvo, Guillermo A., Alejandro Izquierdo, and Ernesto Talvi, 2006, "Phoenix Miracles in emerging markets: Recovering without credit from systemic financial crises," NBER Working Paper 12101

Carroll, Christopher D., Robert E. Hall, and Stephen P. Zeldes, 1992, “The Buffer-Stock Theory of Saving: Some Macroeconomic Evidence," Brookings Papers on Economic Activity, Vo. 1992, Issue 2, pp. 61-156. The Brookings Institution. 
Caselli, Francesca; Federico Grinberg; and Alasdair Scott, forthcoming, "European Recoveries Since the Global Financial Crisis," IMF Working Paper, International Monetary Fund, Washington DC.

Cerra, Valerie; and Sweta Chaman Saxena, 2008, "Growth Dynamics: The Myth of Economic Recovery,” American Economic Review, Vol. 98, No. 1, pp. 438-457.

Chong, Eilyn Yee Lin; Ashoka Mody; and Francisco Varela Sandoval, 2017, "Finance and Growth: The Direction of Causality," VOX, CEPR's Policy Portal.

Claessens, Stijn; M. Ayhan Kose; and Marco E. Terrones, 2011, "How Do Business and Financial Cycles Interact, “ IMF Working Paper, WP/11/88, International Monetary Fund, Washington DC.

Claessens, Stijn M., Ayhan Kose, and Marco E. Terrones, 2009, “A recovery without credit: Possible, but...", VoxEU.org, 22 May 2009.

Claessens, Stijn; M. Ayhan Kose; and Marco E. Terrones, 2009B, "What Happens during Recessions, Crunches and Busts?” Economic Policy Vol. 24 No. 60 pp. 653-700.

Coricelli, Fabrizio, and Isabelle Roland, 2011, "How do Credit Conditions Shape Economic Recoveries,” CEPR Discussion Paper No. DP8325.

Coricelli, Fabrizio and Roland, Isabelle,2011, "How Do Credit Conditions Shape Economic Recoveries?" CEPR Discussion Paper No. DP8325. Available at SSRN: https://ssrn.com/abstract $=1810290$

Deaton, Angus, 1991, "Saving and Liquidity Constraints," Econometrica, Vol. 59, No. 5 (September 1991), pp. 1221-1248.

Del Giovane, Paolu; Ginette Erama; and Andrea Nobili, 2011, "Disentangling Demand and Supply in Credit Developments: A Survey-Based Analysis for Italy," Journal of Banking and Finance, Vol. 35, Issue 10, pp. 2719-2732.

Dumičić, Mirna, and Igor Ljubaj, 2017, "Delayed Credit Recovery in Croatia: Supply or Demand Driven?”, CNB Working Paper W-45, Croatian National Bank, Zagreb.

Eggertsson, Gauti B. and Paul Krugman, 2012, "Debt, Deleveraging, and The Liquidity Trap: A Fisher-Minsky-Koo Approach,” The Quarterly Journal of Economics, Vol. 127, Issue 3, Oxford University Press, pp. 1469-1513.

Everaert, Greetje, Natasha Che, Nan Geng, Bernard Gruss, Gregorio Impavido, Yinqiu Lu, Christian Saborowski, Jerome Vandenbussche, and Li Zeng, 2015, "Does Supply or Demand Drive the Credit Cycle? Evidence from Central, Eastern, and Southeastern Europe," IMF Working Paper, WP/15/15. International Monetary Fund, Washington DC. 
Fisher, Irving, 1933, “The Debt-Deflation Theory of Great Depressions," Econometrica, Vol.1, No. 4, October, pp. 337-357.

Flamini, V., C. McDonald, and L. Schumacher, 2009 "The Determinants of Commercial Bank Profitability in Sub-Saharan Africa” IMF Working Paper WP/09/15

Funke, Manuel; Moritz Schularick; and Christoph Trebesch, 2016, "Going to Extremes: Politics after Financial Crises, 1870-2014," European Economic Review No. 88, pp. 227-260.

Gaspar, Vitor; Maurice Obstfeld; and Ratna Sahay, 2016, "Macroeconomic Management When Policy Space Is Constrained: A Comprehensive, Consistent, and Coordinated Approach to Economic Policy," IMF Staff Discussion Note, SDN/16/09, International Monetary Fund, Washington DC.

Gennaioli, Nicola; Andrei Shleifer; and Robert Vishny, 2012, "Neglected risks, financial innovations, and financial fragility," Journal of Financial Economics, Vol. 104, pp. $452-468$.

Guttentag, Jack M. and Richard Herring, 1984, "Credit Rationing and Financial Disorder," The Journal of Finance, Vol. 39, Issue 5, December, pp. 1359-1382.

IMF, 2008, "From Recession to Recovery: How Soon and How Strong?" chapter 3 in World Economic Outlook, prepared by Marco E. Terrones, Alasdair Scott, and Prakash Kannan, October, International Monetary Fund, Washington DC.

IMF, 2009A, "What's The Damage? Medium-Term Output Dynamics after The Financial Crisis," chapter 4 in World Economic Outlook, prepared by Ravi Balakrishnan, Petya Koeva-Brooks, Daniel Leigh, Irina Tytell, and Abdul Abiad, October, International Monetary Fund, Washington DC.

IMF 2009B, "Financial Stress and Economic Downturns, chapter 4 in World Economic Outlook, prepared by Subir Lall, Roberto Gardarelli, and Selim Elekdag, April, International Monetary Fund, Washington DC.

IMF, 2013, "Assessing Policies to Revive Credit Markets," chapter 2 in the Global Financial Stability Report: Transition Challenges to Stability, prepared by S, Erik Oppers, Nicolas Arregui, Johannes Ehrentraud, Frederic Lambert and Kenichi Ueda, October, International Monetary Fund, Washington DC.

IMF 2015A, “A Strategy for Resolving Europe's Problem Loans” by Aiyar, Shekhar; Wolfgang Bergthaler; Jose M. Garrido; Anna Ilyina; Andreas Jobst; Kenneth Kang; Dmitriy Kovtun; Yan Liu; Dermot Monaghan; and, Marina Moretti, in IMF Staff Discussion Note, SDN/15/19, September, International Monetary Fund, Washington DC. 
IMF, 2015B, "Mind the Credit Gap," Regional Economic Issues: Central, Eastern, and Southeastern Europe, by Ernesto Crivelli, Anna Ilyina, Plamen Iossifov, Jiri Podpiera, Ara Stepanyan, Faezeh Raei, and Jiae Yoo, May, International Monetary Fund, Washington DC.

Jamaludin, F., V. Klyuev, and A. Serechetapongse, 2015 "What Drives Interest Rate Spreads in Pacific Island Countries? An Empirical Investigation" IMF Working Paper WP/15/96, International Monetary Fund, Washington DC.

Jordà, Oscar; Moritz Schularick; and Alan M. Taylor, 2014, "Sovereigns versus Banks: Credit, Crises, and Consequences," Working Paper Series 2013-37, Federal Reserve Bank of San Francisco.

Jordà, Oscar and Alan M. Taylor, 2013A, "When Credit Bites Back," Journal of Money Credit and Banking Vol. 45, Issue s2, pp. 3-28.

Jordà, Oscar; Moritz Schularick; and Alan M. Taylor, 2012, "When Credit Bites Back: Leverage, Business Cycles, and Crisis,” Working Paper Series 2011-27, Federal Reserve Bank of San Francisco.

Jordà, Oscar, 2005, "Estimation and Inference of Impulse Responses by Local Projections," American Economic Review, Vol. 95, No.1, March, pp. 161-182.

Juselius, Mikael; and Matthias Drehmann, 2016, "Leverage Dynamics and the Burden of Debt,” Bank of Finland Research Discussion Paper, No. 3, Bank of Finland, Helsinki.

Juselius, Mikael; and Matthias Drehmann, 2014, "Growth less Credit Booms and Creditless Recoveries," Working Paper, preliminary draft.

Kindleberger, Charles, 1978, Manias, panics and crashes. Macmillan, London.

Kiyotaki, Nobuhiro, and John Moore, 1997, “Credit Cycles," Journal of Political Economy, Vol. 105, No. 2, pp. 211 - 48. The University of Chicago Press.

Knight, Frank H. (1921) Risk, Uncertainty, and Profit. Boston, MA: Hart, Schaffner \& Marx; Houghton Mifflin Company.

Koo, Richard, 2011, "The World in Balance Sheet Recession: Causes, Cure, and Politics", Real-World Economics Review, No. 58, December, pp.19-37, http://www.paecon.net/PAEReview/issue58/Koo58.pdf

Koo, Richard, 2003, The Holy Grail of Macroeconomics: Lessons from Japan's Great Recession, John Wiley \& Sons. 
Kose, M. Ayhan, and Marco E. Terrones, 2015, Collapse and Revival: Understanding Global Recessions and Recoveries, International Monetary Fund, Washington D.C.

Kroszner, Randall, Luc Laeven, and Daniela Klingebiel, 2007, "Banking Crises, Financial Dependence, and Growth," Journal of Financial Economics, Volume 84, Issue 1, April, Pages: 187-228

Laeven, Luc; Lev Ratnovksi; and Hui Tong, 2014, "Bank Size and Systemic Risk," IMF Staff Discussion Note, SDN/14/04, May, International Monetary Fund, Washington DC.

Laeven, Luc; and Fabián Valencia, 2012, "Systemic Banking Crises Database: An Update," IMF Working Paper No. WP/12/163, International Monetary Fund, Washington DC.

Levine, Ross, Norman Loayza, and Thorsten Beck, 2000, "Financial Intermediation and Growth: Causality and Causes," Journal of Monetary Economics,46 (2000), 31-77.

Laibson, David, 1997, “Golden Eggs and Hyperbolic Discounting,” The Quarterly Journal of Economics, May, pp. 443-78.

Lian, Weicheng; Sergejs Saksonovs; Gabriel Srour; and Shekhar Aiyar, 2014, "Creditless Recovery in The Baltic Countries," chapter 2 in the 2014 Baltic Cluster Report: Selected Issues, International Monetary Fund, Washington DC.

Loayza, Norman and Rancière, Romain, 2006," Financial Development, Financial Fragility, and Growth," Journal of Money, Credit and Banking, 38(4), 1051-1076.

Mendoza, Enrique and Marco Terrones, 2012, "Anatomy of Credit Booms and Their Demise," Journal Economia Chilena (Journal of the Chilean Economy), Central Bank of Chile, vol. 15 (2), pp. 4-32.

Meriküll, Jaanika, 2015, "Household Borrowing During a Creditless Recovery,” Emerging Markets Finance and Trade, Vol. 51, Routledge, Taylor \& Francis Group, pp. 10511068.

Mian, Atil; Amir Sufi, and Emil Verner, 2015, "Household Debt and Business Cycles Worldwide," NBER Working Paper No. 21581, National Bureau of Economic Research, Cambridge MA.

Mian, Atif and Amir Sufi, 2014, House of Debt: How They (And You) Caused The Great Recession, And How We Can Prevent It from Happening Again, The University of Chicago Press,

Nassar, K.B., E. Martinez, and A. Pineda, 2014 “Determinants of Banks' Net Interest Margins in Honduras" IMF Working Paper WP/14/163

Podpiera, Jiři; Faezeh Raei; and Ara Stepanyan, 2017, "A Fresh Look at Potential Output in Central, Eastern, and South Eastern European Countries," IMF Working Paper No. 17/37, International Monetary Fund, Washington DC. 
Poghosyan, T. and H. Hesse, 2009 "Oil Prices and Bank Profitability: Evidence from Major Oil-Exporting Countries in the Middle East and North Africa" IMF Working Paper $\mathrm{WP} / 09 / 220$.

Rajan, Raghuram and Luigi Zingales, 1998, "Financial Dependence and Growth," The American Economic Review, Volume 88, No 3, June Pages: 559-586.

Randall, Wray L., 2016, Why Minsky Matters: An Introduction to the Work of a Maverick Economist, Princeton University Press, Princeton.

Reinhart, Carmen M. and Kenneth S. Rogoff, 2009, This Time is Different: Eight Centuries of Financial Folly, Princeton University Press.

Roodman, David (2009), “A Note on the Theme of Too Many Instruments.” Oxford Bulletin of Economics and Statistics, Volume 71, Issue 1 February 2009 Pages 135-158.

Rousseau, Peter L. and Paul Wachtel, 1998, "Financial Intermediation and Economic Performance: Historical Evidence from Five Industrial Countries,” Journal of Money, Credit, and Banking, November 1998, 30(4), 657-78.

Spatafora, Nicola and Oana Luca, 2012, "Capital Inflows, Financial Development, and Domestic Investment; Determinants and Inter-Relationships," IMF Working Papers 12/120, International Monetary Fund.

Strotz, R. H., 1955, "Myopia and Inconsistency in Dynamic Utility Maximization," The Review of Economic Studies, Vol. 23, No. 3, pp. 165-80. Oxford University Press.

Sugawara, Naotaka and Juan Zalduendo, 2013, "Credit-less Recoveries," Policy Research Working Paper No. 6459, World Bank, Washington DC.

Takáts, Előd and Christian Upper, 2013, "Credit and Growth after Financial Crises," BIS Working Papers, No. 416, Bank for International Settlement, Basel.

Taylor, Alan M., 2015, “Credit, Financial Stability, and The Macroeconomy," Discussion Paper Series No. 10511, Centre for Economic Policy Research, London

Wu, Jing Cynthia and Xia, Fan Dora, "Measuring the Macroeconomic Impact of Monetary Policy at the Zero Lower Bound," Journal of Money, Credit, and Banking, 2016, 48(23), 253-291

Yao, Shuijie and Jing Zhang, 2011, “On Economic Theory and Recovery of the Financial Crisis," The World Economy, Blackwell Publishing Ltd, USA, pp. 764-777. 